\title{
A 20-YEAR LONG TERM STUDY OF YIELD SUSTAINABILITY AND SOIL FERTILITY AFFECTED BY FERTILIZATION AND APSIM CLIMATIC CHANGE MODEL OF URUMQI, XINJIANG, CHINA
}

\author{
TAHIR, N. ${ }^{1}-$ LI, J. $^{1 *}-$ MA, Y. ${ }^{2}-$ ULLAH, A. ${ }^{1}-$ LIU, H. ${ }^{3}$ \\ ${ }^{1}$ Institute of Agricultural Resources and Regional Planning, Chinese Academy of Agricultural \\ Sciences, 12 Southern Street of Zhongguancun, Beijing 100081, China \\ ${ }^{2}$ Macau Environmental Research Institute, Macau University of Science and Technology, \\ Macau 999078, China \\ ${ }^{3}$ Institute of Soil Fertilizer and Agricultural Water Saving, Xinjiang Academy of Agricultural \\ Sciences, Urumqi 830000, Xinjinag, China \\ (phone: +86-1-5652-493-881) \\ *Corresponding author \\ e-mail:lijumei@caas.cn
}

(Received $8^{\text {th }}$ Dec 2020; accepted $3^{\text {rd }}$ Mar 2021)

\begin{abstract}
To achieve high crop production, long-term field experiments 20 years (1990-2010) were conducted at Urumqi-China. In this study, we investigate the effect of organic and inorganic fertilization treatments on maize, spring wheat, and winter wheat cropping system in Urumqi, Xinjiang China. We investigated the impact of soil fertility, crop yield sustainability index, nutrients balance, carbon sequestration (CSR), and climatic change model through the Agricultural Production Systems Simulator (APSIM). Five treatments were studied: CK (control); NPK (inorganic fertilizers nitrogen, phosphorus, and potassium); NPKM and manure; NPKS \& straw and NPKM2 and manure (the rate of manure was double from NPKM. The study showed that the combined application of inorganic and manure application (NPKM2 and NPKM) significantly increased the crop grain yield and soil fertility and sustainable yield index were higher as compared to NPK and CK. The changes of maximum and minimum temperature (+2), decreasing precipitation (-10), and increased $\mathrm{CO}_{2}$ level (350-650 ppm) from observed values, simulated in the climatic model will significantly decrease essential soil water (191.2$181.1 \mathrm{~mm})$, runoff $(0.43-0.40 \mathrm{~mm})$, total $\mathrm{NO}_{3}{ }^{-}$(1444.0 to 1422.5$) \mathrm{kg} \mathrm{ha}^{-1}$, and leaching $(0.75-0.73)$ and runoff $(0.43 \mathrm{~mm}$ to $0.40 \mathrm{~mm})$ while increased total $\mathrm{NH}_{4}{ }^{+}(35.1$ to 41.72$) \mathrm{kg} \mathrm{ha}^{-1}$.
\end{abstract}

Keywords: long-term fertilization, nutrients balance, nutrient input, carbon sequestration rate

\section{Introduction}

Nowadays the Chinese government is focusing on the increasing food crisis and the priority is to produce adequate food for their huge population. For sustainability in food supply to the whole world and especially in China, proper agriculture management practices are needed (Ullah et al., 2020). The application of synthetic fertilizers to achieve maximum crop yield is common practice in agriculture management (Gaind, 2007). Development in scientific data calculations and field management technologies has caused a significant increase in crop production (Doltra et al., 2019). Tong et al. (2003) reported that high-yielding varieties and large consumption of chemical fertilizers increased the annual production of crops in China by 3.37\% during 19701990 (FAO, 2009). While 0.6\% decrease in yield was noted during 1990-2006 (FAO, 2009), which might have been due to the impact of climate change (Zhang et al., 2013) 
and might be further affected by global climate changes (Lobell, 2003). Long-term application of synthetic fertilizers will cause soil deterioration that will decrease crop production, nutritional disorder, groundwater quality, and damage the environment through nonpoint source pollution (Jin et al., 2005; Zhao et al., 2020). Therefore, many scientists have suggested the use of organic fertilizers over chemical fertilizers (Bakht et al., 2009) that will increase soil carbon storage to tackle the problem of global climate change and food security (Zhao et al., 2020). However, use of inorganic fertilizers in excess form increase the water and atmospheric pollution (Derpsch, 2003), but mineral fertilizers through excessive usage in the soil system led to the environmental risk such as water quality (Chen et al., 2008).

To explore and assess the study of overall soil fertility the long-term fertility experiments have been important resources in modern-day science (Shahid et al., 2016). From the perspective of agricultural sustainability, long-term experimentation has provided a platform to investigate soil quality, productivity, and crop yield trends for a long period (Rasmussen et al., 1998). Irrigation and fertilization are considered important factors for nutrient deposition in the soil to obtain high agricultural production however, other factors, such as soil type, fertilization pattern, pests, climate, and cultivars also affect the crop productivity and soil sustainability in long-term cropping systems (He et al., 2020). The SYI stands for a sustainable yield index and represents the actual yields over a long period. It is a quantitative measuring unit to assess the sustainability of agricultural practice (Stull et al., 2004). Countries producing high yield over the years through advanced management and cultivation practices will have higher SYI and sustainability (Singh et al., 2017; Saha et al., 2018). Rasmussen et al. (1998) stated that the sustainability of an agricultural system can be measured through long-term experiments while Tong et al., 2003 reported that early warning systems for the future can be created from the data developed through long-term experiments.

The decline in soil fertility of Chinese soil has been reported by many long-term fertility experiments through extensive variation in crop yields. The continued nitrogen management is very important in this regard for sustainable crop production and soil protection (Tong et al., 2003; Xin et al., 2017; Hu et al., 2019). Chemical fertilizers should be replaced with organic fertilizers to improve phosphorous use efficiency and enhance soil fertility (Xin et al., 2017). Crop simulation models are considered as potentially valuable tools for the accompaniment and advancement of field observations. Crop simulation models deliver a clear demonstration of the essential biological and physical processes such as plant growth and development, nutrients, and water dynamics of single to multiple cropping seasons (Watson et al., 2002; Beaudoin et al., 2008; Kollas et al., 2015). These models provide the opportunity to study the short and long-term effects of new or ongoing agricultural management techniques on crop rotations under the range of different environmental and soil conditions. Worldwide, crop simulation models like APSIM (Keating et al., 2003a), STICS (Brisson, 2003) and DSSAT (Jones et al., 2003) were developed and used for crop simulation but few of these models were reported to have been used under maize-wheat crop rotation (Watson et al., 2002). Increasing the nitrogen fertilizer application in conventional crop rotation will decrease the weight of mineralization in nitrogen balances. Therefore, simple modeling and positive response of the crop to mineral $\mathrm{N}$ inputs are comparatively far significant than predicting nitrogen mineralization in upright model performance in these systems.

In this study, we evaluate the ability of the APSIM model to study the effects of different fertility management options in a mono-cropping region having maize, spring 
wheat, and winter wheat cropping system. The APSIM soil nitrogen and climatic model was used to identify nitrogen leaching, field water holding capacity (DUL), saturated water content (SAT), drainage, runoff, total $\mathrm{NO}_{3}{ }^{-}$, and $\mathrm{NH}_{4}{ }^{+}$, on the long-term soil fertilization treatments of soil over 20 years (1990-2010) in Urumqi Xinjiang, China. Data from the long-term field was used, such as soil, crop and climatic conditions provide a rich dataset for model testing and evaluation. The second objective of the study was to investigate the effects of a different combination of synthetic and organic (sheep-manure) fertilization on sustainable crop production, nutrient uptake, nutrient balance, and relative yield under a mono-cropping system in the Haplic calcisol (grey desert soil). The investigation of nutrients and yield was also carried out for better soil fertility and crop production.

\section{Materials and methods}

\section{Location and site description}

The long-term research station was established in Urumqi, Xinjiang, China. This region is a semi-arid and continental cold region, with a difference between winters and summer. The latitude and longitude of the area are about $43^{\circ} 49^{\prime} 31^{\prime \prime} \mathrm{N} 87^{\circ} 37^{\prime} 00^{\prime \prime} \mathrm{E}$; elevation $600 \mathrm{~m}$ above sea level and it has warm and hot summers. The maximum temperature and precipitation were $15.2^{\circ} \mathrm{C}$ and $360.1 \mathrm{~mm}$ while the minimum temperature and precipitation were $12.65{ }^{\circ} \mathrm{C}$ and $141 \mathrm{~mm}$. The experiments were conducted under semi-arid land conditions on the well-fertilized Haplic calcisol (Grey desert soil based on the FAO soil classification) (Zhang et al., 2010). The dataset was used to parameterize the APSIM-Maize-wheat model, nitrogen, and climatic Model. The soil and crop data were also recorded for each crop. The mean annual temperature (MAT) and mean annual precipitation (MAP) for the experimental period were shown in Figure 1. The site detail, fertilizer input, and soil sampling procedure were described in Table 1 and Figure 2.

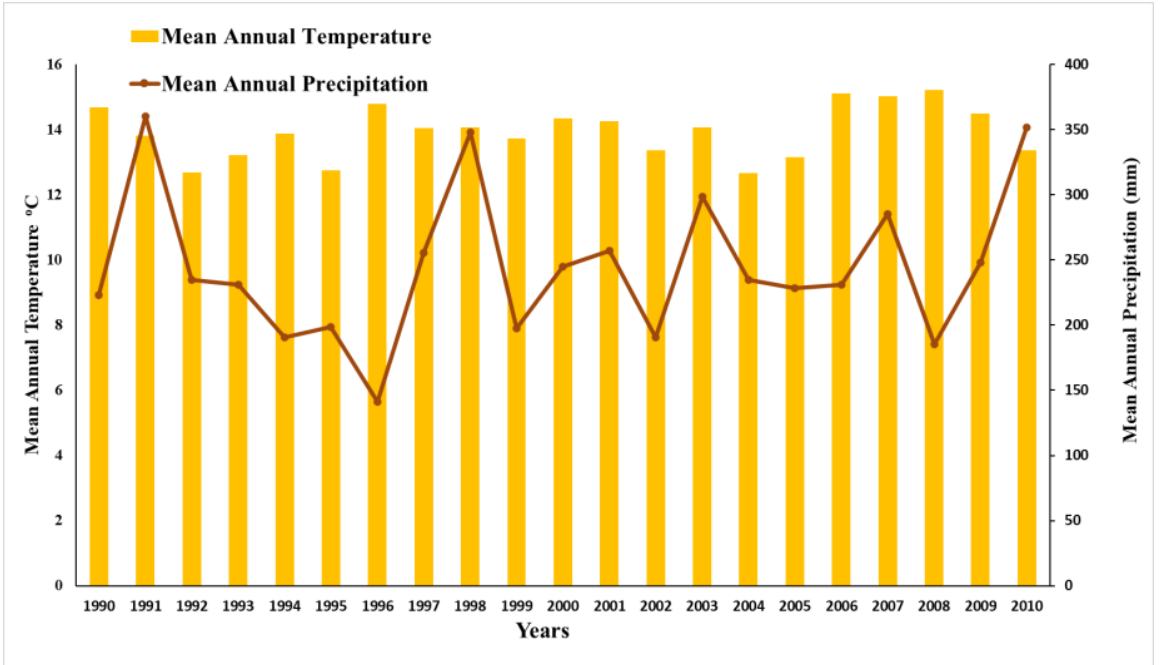

Figure 1. The meteorological data mean annual temperature (MAT) and mean annual precipitation (MAP) during long term fertilization. The total precipitation was $4537.1 \mathrm{~mm}$ from the years (1990-2010). The annual average ambient temperature TAV was $7.86\left({ }^{\circ} \mathrm{C}\right)$ and the annual amplitude in the mean monthly temperature was $41.03\left({ }^{\circ} \mathrm{C}\right)$ calculated by the APSIM software. The weather data was daily data which was converted to mean annual average data 


\section{Geographic Location of the Study Area}

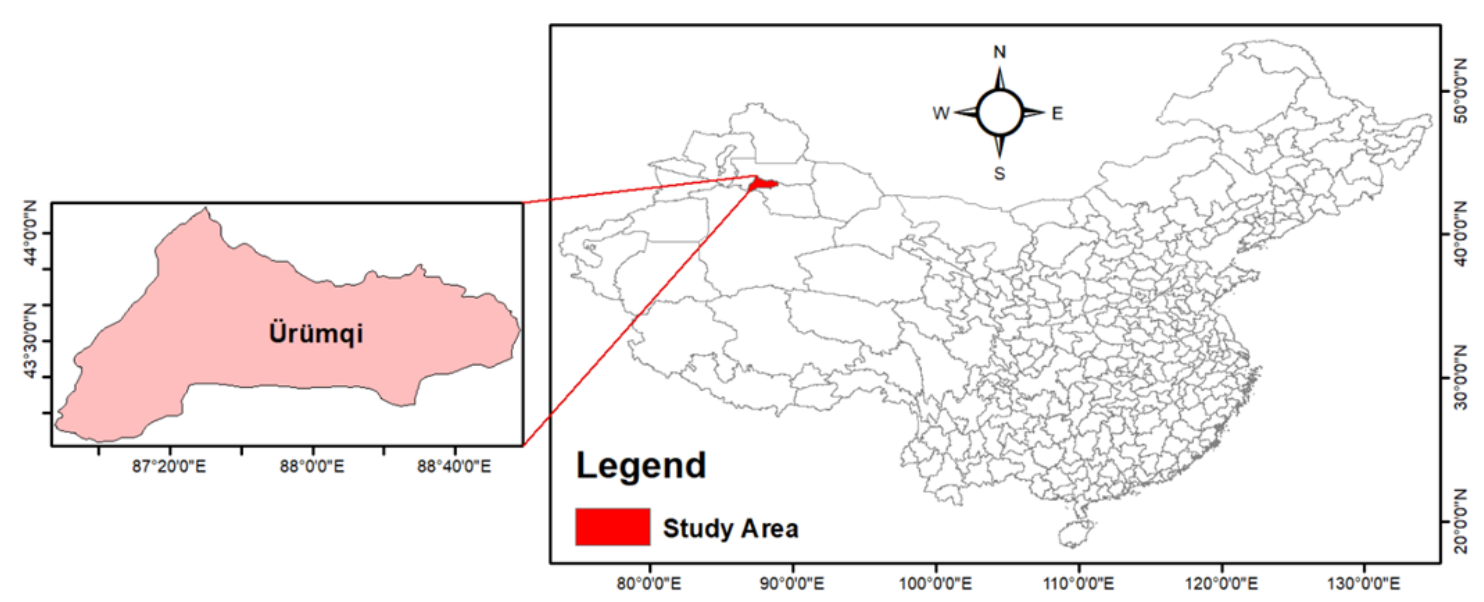

Figure 2. Study site long term fertilization experiment in Urumqi, Xinjiang China the map was made by ARC-GIS using the coordinates of the location

Table 1. Initial soil physical and chemical properties at the long-term experimental site of Urumqi, Xinjiang, China

\begin{tabular}{|c|c|}
\hline Sites & Urumqi \\
\hline China soil classification & Grey desert soil (Sandy loam) \\
\hline FAO soil classification & Haplic Calcisol \\
\hline Soil organic carbon ${ }^{\mathrm{b}}\left(\mathrm{g} \mathrm{kg}^{-1}\right)$ & 8.8 \\
\hline Total $\mathrm{N}^{\mathrm{c}}\left(\mathrm{g} \mathrm{kg}^{-1}\right)$ & 0.91 \\
\hline $\mathrm{C} / \mathrm{N}$ ratio & 10.4 \\
\hline Total $\mathrm{P}^{\mathrm{d}}\left(\mathrm{g} \mathrm{kg}^{-1}\right)$ & 0.67 \\
\hline Total $\mathrm{K}^{\mathrm{e}}\left(\mathrm{g} \mathrm{kg}^{-1}\right)$ & 23.0 \\
\hline Available $\mathrm{N}\left(\mathrm{mg} \mathrm{kg}^{-1}\right)$ & 55.2 \\
\hline Available-P (mg kg $\left.{ }^{-1}\right)$ & 3.4 \\
\hline Available K (mg kg$\left.{ }^{-1}\right)$ & 288 \\
\hline $\mathrm{pH}^{\mathrm{a}}$ & 8.1 \\
\hline Clay content $(<0.002 \mathrm{~mm})(\%)$ & 20.9 \\
\hline Bulk density $\left(\mathrm{g} \mathrm{cm}^{-3}\right)$ & 1.25 \\
\hline Altitude (m) & 600 \\
\hline Cropping system & (Maize-Spring wheat-winter wheat) \\
\hline Annual precipitation $(\mathrm{mm})$ & $280-320$ \\
\hline Solar radiation $(\mathrm{h})$ & $2550-3500$ \\
\hline
\end{tabular}

Annual precipitation, temperature, effective accumulated temperature and sunshine hours are means over 20-years (1990-2010). MAT: mean annual temperature. EAT; effective accumulated temperature. (a) Measured in 1:5 soil: ratio, (b) Measured by the Walkley wet combustion method (Nelson and Sommers, 1996), (c) Total $\mathrm{N}$ measured by the Kjeldahl method (Nelson and Sommers, 1996), (d) Available P with 0.5 M NaHCO3 (Murphy and Riley, 1962), (e) Exchangeable K with N ammonium acetate (Richardson et al., 2009). Soil available N, P, and K were measured by Lu et al. (2000) (Olsen et al., 1954) and total nitrogen (TN), total phosphorus (TP) and total potassium (TK) in soils were determined using micro-Kjeldahl digestion, colorimetric analysis and a dissolution-flame photo- meter, separately (Page et al., 1982), respectively 


\section{Experimental design}

The study was conducted with different treatments consisting of inorganic and organic fertilization. The experiment consisted of five different treatments of fertilization and was conducted during 1990-2010. We selected five treatments in the fertilization dynamic study (Table 2): (1) CK (no fertilization); NPK (inorganic nitrogen, phosphorous and potassium fertilizer); (3) NPKM (inorganic NPK fertilizer and manure); (4) NPKS (inorganic NPK fertilizer and straw), and (5) NPKM2 (inorganic NPK fertilizer and manure with double the amount of NPKM). The study period was from 1990-2010. The fertilizer details, annual input rate of manure, and inorganic fertilizer are given in Table 2.

\section{Crop and soil management}

The cropping system was a mono-cropping system (maize-spring wheat-winter wheat). Extensively used local maize and wheat varieties were selected for cultivation, the variety detail and planting detail were given in Table A1. The crop samples were finely ground to pass a $0.15-\mathrm{mm}$ sieve. To determine the total $\mathrm{P}$ (TP) content, the plant samples were digested with $\mathrm{H}_{2} \mathrm{SO}_{4}-\mathrm{H}_{2} \mathrm{O}_{2}$ following the method of (Jackson.,1969), and concentration in the digesting solution was measured using the molybdenum-blue colorimetric method (Page et al., 1982). The winter wheat average sowing date was September $28^{\text {th }}$; harvest date was July $10^{\text {th }}$. The average sowing date of spring wheat was April $3^{\text {th }}$; the harvest date was July $20^{\text {th }}$. The average sowing period of corn was May $1^{\text {st; }}$, the harvest period started on September $20^{\text {th }}$. The irrigation time for winter wheat was 7 times, for spring wheat it is 5 times, and Maize 6 times. After the crops were harvested, they were irrigated in winter and turned in autumn at a depth of $30-40 \mathrm{~cm}$. Before sowing, the soil is only raked and level' and furrowed. Inter tillage should be carried out during crop growth, winter wheat inter tillage once, and topdressing at the same time (April 18); spring wheat inter tillage once, and topdressing at the same time (May 13); corn inter tillage twice, in the seedling stage (May 10th), and (June 25th). In maize the plants ranged of 4,000 to 5,000 plants per ha with a row spacing of about $70 \mathrm{~cm}$, and plant spacing of $25-30 \mathrm{~cm}$. While wheat (winter and spring) row spacing was $40 \mathrm{~cm}$. The nitrogen fertilizer was urea, phosphate fertilizer was superphosphate, potash fertilizer is potassium sulfate, organic fertilizer $M$ was sheep manure, and $S$ was straw. In the chemical fertilizer, $60 \%$ nitrogen fertilizer and all phosphorus and potassium fertilizers were used as base fertilizer, and $40 \%$ nitrogen fertilizer was used as topdressing. The crop was harvested; after harvest, the grain and straw were air-dried and weighed. The management practice were hand weeding and bird frightening methods were used to prevent grain loss from anthesis to harvest. Soil samples from $0-20 \mathrm{~cm}$ were taken once in the first week of October every year, approximately 15 days after crop harvesting in fall for all sites after every year. The samples were thoroughly mixed to make the composite sample, air-dried, and transferred to the laboratory for soil analysis. Soil bulk density was calculated on undisturbed soil samples that were collected with a cutting ring of 50.46-mm inner diameter, $100 \mathrm{~cm}^{3}$ volume, and 50-mm depth of soil sampling (Pansu, 2006). After the crop was harvested, all air-dried and oven-dried grains and straw samples were kept for $30 \mathrm{~min}$ at $105^{\circ} \mathrm{C}$ for the calculation of dry matter and nutrient contents. The plant nitrogen, phosphorous, and potassium content were measured through Kjeldahl digestion and vanadomolybdate yellow method, and flame photometer respectively. Nutrient uptake was determined by multiplying plant nutrient content with yield. To determine the chemical properties of the soil samples, all the method was described in the note section of Table 1. 
Table 2. Annual input rate of organic (sheep manure) and inorganic $N$ (nitrogen), $P$ (phosphorous), $K$ (potassium) fertilizer added to various treatments of a long-term experiment in a maize-wheat cropping system. Notes: CK (Control), no fertilizer; NPK, chemical nitrogen, phosphorus, and potassium; NPKM, chemical NPK, and manure; NPKS, chemical nitrogen, phosphorus, and potassium and straw; NPKM2, double in manure from $N P K M$

\begin{tabular}{c|c|c|c|c}
\hline Treatments & $\begin{array}{c}\mathbf{N} \\
\left(\mathbf{k g ~ h a}^{-\mathbf{1}}\right)\end{array}$ & $\begin{array}{c}\mathbf{P}_{2} \mathbf{O}_{\mathbf{5}} \\
\left(\mathbf{k g ~ h a}^{\mathbf{- 1}} \mathbf{)}\right.\end{array}$ & $\begin{array}{c}\mathbf{K}_{\mathbf{2}} \mathbf{O} \\
\left(\mathbf{k g ~ h}^{\mathbf{- 1}} \mathbf{)}\right.\end{array}$ & $\begin{array}{c}\text { Organic fertilizer } \\
\left(\mathbf{k g ~ h a} \mathbf{~}^{-\mathbf{1}} \mathbf{)}\right.\end{array}$ \\
\hline CK & 0 & 0 & 0 & 0 \\
NPK & 241 & 138 & 58 & 0 \\
NPKM & 85 & 51 & 12 & 30,000 \\
NPKS & 217 & 117 & 51 & 450 \\
NPKM2 & 150 & 90 & 18 & 60,000 \\
\hline
\end{tabular}

The nitrogen fertilizer was urea, the phosphate fertilizer was superphosphate, the potassium fertilizer was potassium sulfate and the organic fertilizer $\mathrm{M}$ was sheep manure. $60 \%$ of the nitrogen fertilizer and all the phosphorus and potassium fertilizers was used as the base fertilizer, and $40 \%$ of the nitrogen fertilizer was used as the top dressing. The sheep manure contains $7 \mathrm{~g} \mathrm{~kg}^{-1}$ of N, $3.2 \mathrm{~g} \mathrm{~kg}^{-1}$ of P, and $8 \mathrm{~g}$ $\mathrm{kg}^{-1}$ of $\mathrm{K}$

\section{Calculations}

The SOC density content was calculated from SOC content by the equation (Lal, 2008):

$$
\text { Socdensity }=\text { Soc content } x d x B D \times 10
$$

where soil organic carbon density was in $\left(\mathrm{Mg} \mathrm{ha}^{-1}\right) \mathrm{SOC}_{\text {density }}$; soil organic carbon content was in $\left(\mathrm{g} \mathrm{kg}^{-1}\right)$ represented by $\mathrm{SOC}_{\text {content}}$; $\mathrm{d}$ is the depth of the soil while BD is the depth of the soil layer $(0.20 \mathrm{~m})$ and soil bulk density $\left(\mathrm{g} \mathrm{cm}^{-3} / \mathrm{kg} \mathrm{m}^{-3}\right)$. Soil organic carbon (SOC), as an index for soil fertility and a mean for carbon sequestration, has attracted much attention over the past decades. Soil fertility index was measured by soil organic carbon rate (SOC) and means of sequestration of carbon. The soil sequestration rate of organic carbon (CSR, $\mathrm{t} \mathrm{ha}^{-1} \mathrm{year}^{-1}$ ) was calculated by the following equation (Zhang et al., 2012).

$$
\operatorname{CSR}=\frac{(\text { SOCT }- \text { SoCo })}{t}
$$

where CSR is the Soil sequestration rate, SOCT and SOC 0 is organic carbon $\left(\mathrm{t} \mathrm{ha}^{-1}\right)$ stock at the time (t) and in the first year (1990), respectively and (t) was the period of experimentation (20 years). The relative yield (YR) was measured to study the comparison of individual treatment of yield data. YR was calculated through the following formula (Singh et al., 1990).

$$
\text { YR }=\text { Ytreatment }- \text { Ycontrol }
$$

where $\mathrm{Y}_{\text {treatment }}$ is the yield of treatment of fertilizer applied $\left(\mathrm{t} \mathrm{ha}^{-1}\right)$ in a particular year of experimentation and $Y_{\text {control }}$ is the yield $\left(\mathrm{t} \mathrm{ha}^{-1}\right)$ in the same year of control treatment. 
Sustainable yield index (SYI) is a quantitative extent to measure the productivity of long-term land management (Stull et al., 2004). The SYI was measured by using the following equation (Singh et al., 1990):

$$
\text { Sustainable yield index }(\text { SYI })=\frac{\text { Ymean }-\sigma}{\text { Ymax }}
$$

where $Y_{\text {mean }}$ is a mean of yield treatment, $\sigma$ is the treatment standard deviation, and $Y_{\max }$ is the maximum yield over the years for every treatment.

Apparent nutrient balance $(\mathrm{AB})$ defined as the difference between entering nutrient inputs in the farming system and leaving nutrients from the farming system (OECD, 2013). AB ( $\mathrm{kg} \mathrm{ha}^{-1}$ year $^{-1}$ ) was measured using the equation as follows (Ouyang et al., 2017):

$$
\text { Apparent nutrient balance }=\text { Sum of nutrient input }- \text { Sum of nutrient output }
$$

where nutrient input $\left(\mathrm{kg} \mathrm{ha}^{-1} \mathrm{year}^{-1}\right)$ is annual nitrogen, phosphorus, and potassium input to the field through inorganic and organic fertilization. Nutrient output $\left(\mathrm{kg} \mathrm{ha}^{-1}\right)$ is nitrogen, phosphorus, and potassium uptake $\left(\mathrm{kg} \mathrm{ha}^{-1}\right)$ by the crop in above-ground biomass. If apparent nutrient balance indicates positive value then nutrients are in excess and surplus and if the negative value comes then nutrients are deficit, which indicates decreasing soil productiveness and fertility (OECD, 2013).

\section{APSIM model}

The Agricultural Production Systems Simulator (APSIM) was developed in Australia, the model enables the analysis of complex soil and crop issues for better agriculture production and simulation (McCown et al., 1996; Keating et al., 2003b). APSIM simulates the point scale system in soil and crop. It used daily weather data and utilized the soil physicochemical properties and crop physiological growth process was measured. In the present study, the following models were used such as crop (maize and wheat), soil N (SOILN2), soil water (SOILWAT2), crop residue (RESIDUE2), soil runoff $(\mathrm{mm})$ and climatic change model. The soil runoff was measured by the APSIM climatic change model to check $\mathrm{N}$ losses from the soil system. All these models were linked in the APSIM framework. All the soil parameters and crop water requirements were adjusted with the help of the following website (https://www.apsim.info/wpcontent/uploads/2019/10/Parameters-for-soil-water-Ver24.pdf). All the input parameters were described in Table A2. The date of the simulation was started from 1990-2010. The APSIM met data was calculated with the help of the following website. https://www.apsim.info/support/apsim-training-manuals/creating-an-apsim-met-fileusing-excel/. The soil physical parameters requirement was given in Tables A2 and A3. This table was calculated on the basis of bulk density and used as input measurement in the APSIM model.

\section{Statistical analysis}

The change among different fertilization treatments under long-term fertilization was divided into (1990-2000) and (2000-2010). The simple linear regression model was used for OC and yield graphs among different treatments. The $\mathrm{pH}, \mathrm{AN}, \mathrm{AP}, \mathrm{OC}, \mathrm{TN}, \mathrm{TP}$, and RY were used as dependent variables. The APSIM observed and simulated data were 
undertaken and verified from regression analysis methods. The correlation analysis and Principal component analysis (PCA) were performed through Software R ( $\mathrm{R}$ version 3.6.1,) core team, Vienna, Australia, and this was used for graphical explanation of mean values of treatment effects throughout 1990-2010 on different parameters. The PCA was used for the classification and graphical representation of the components. It gives group accessions of the properties with the highest discrimination values among the variables.

\section{Results}

\section{Crop yield and sustainability index}

The result of the long-term fertilization on the maize-spring wheat-winter wheat cropping system showed significant influences over the fertilization years. The regression trend shown in Figure 3 and grain yield $\left(\mathrm{t} \mathrm{ha}^{-1}\right)$ in Table 3 showed an increase in NPKM2, NPKS and NPKM, and a decrease in control while slight difference was observed in NPK among all the crops. The treatment (NPKM2) showed significant regression trend in maize crop $\left(R^{2}=0.5892\right)$, spring wheat $\left(R^{2}=0.7872\right)$, and winter wheat $\left(R^{2}=0.5447\right)$. The annual grain yield in different fertilization years showed a significant decrease in control among all the treatments and it was the highest in NPKM, NPKS, and NPKM2. The treatment effects in fertilization from 1990-2000 were compared with (2000-2010), an increase in annual grain yield was observed in (2000-2010) in NPKM2, NPKM, and NPKS. In maize and spring and winter wheat, the control showed a decrease in annual grain yield while in NPK slight increase was observed. The sustainable yield index (SYI) increases in organic and inorganic (sheep manure) application in combined and pure doses while in NPK, and NPKM the sustainable yield index was high in winter wheat such as $0.64 \pm 0.28$ and $0.64 \pm 0.29$ followed by NPKM2 $(0.61 \pm 0.26)$. The SYI in maize crop showed the increased value in NPKS, NPKM2, NPKM, and NPKM2 treatment as compared to control. In spring wheat NPKS showed a higher sustainable yield index followed by NPK, NPKM and NPKM2. Moreover, the winter wheat was more sustainable as compared to spring wheat and maize crop.

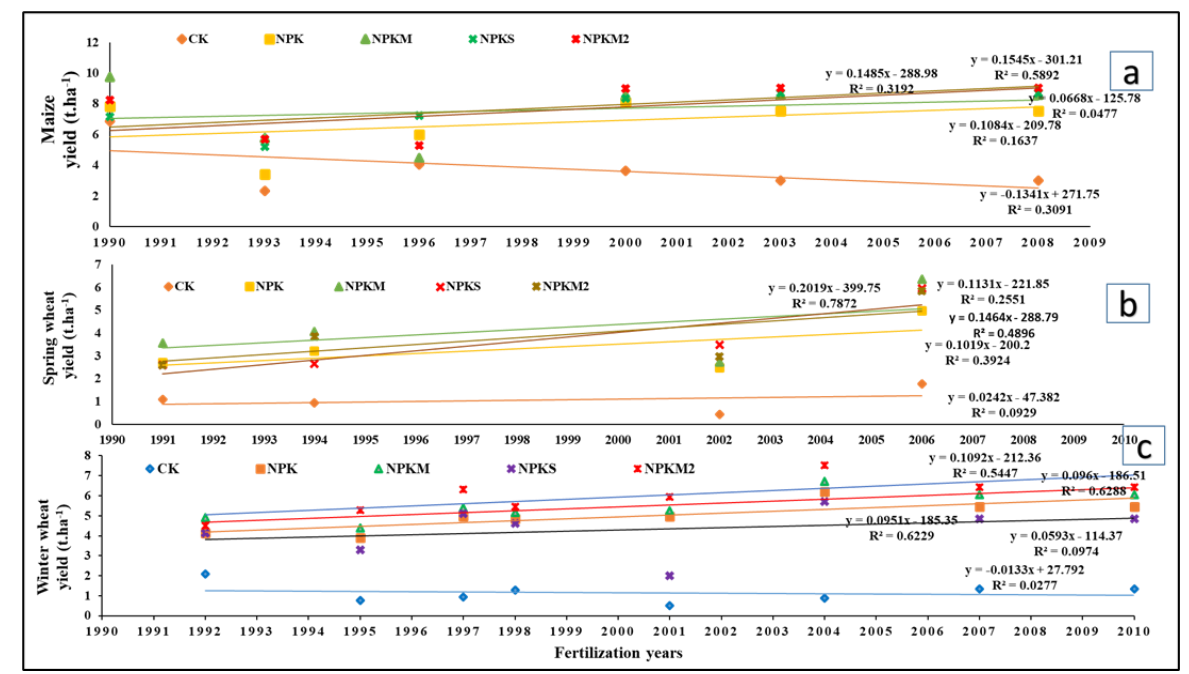

Figure 3. Yield of crops vs fertilization years, the year of fertilization started from 1990-2010, hence each crop grows at different years as presented in the figure: maize (a), spring wheat (b), and winter wheat (c) under various fertilization years of a long-term experiment in the monocropping area of Urumqi, Xinjiang China 
Table 3. Sustainability yield index (SYI) winter wheat, (SYI) of maize and (SYI) of spring wheat under long term experiment having different fertilization dynamics in the monocropping system

\begin{tabular}{c|c|c|c}
\hline Treatments & $\begin{array}{c}\text { SYI } \\
\text { (winter wheat) }\end{array}$ & $\begin{array}{c}\text { SYI } \\
\text { (maize) }\end{array}$ & $\begin{array}{c}\text { SYI } \\
\text { (spring wheat) }\end{array}$ \\
\hline CK & $0.44 \pm 0.09$ & $0.76 \pm 0.12$ & $0.77 \pm 0.15$ \\
NPK & $0.64 \pm 0.28$ & $0.84 \pm 0.11$ & $0.84 \pm 0.09$ \\
NPKM & $0.64 \pm 0.29$ & $0.84 \pm 0.16$ & $0.83 \pm 0.11$ \\
NPKS & $0.56 \pm 0.19$ & $0.94 \pm 0.04$ & $0.89 \pm 0.10$ \\
NPKM2 & $0.61 \pm 0.26$ & $0.89 \pm 0.11$ & $0.79 \pm 0.04$ \\
\hline
\end{tabular}

Values are means of year \pm standard deviations

\section{Apparent nutrient balances and nutrient uptake}

The Nutrient balance is defined as the difference between the nutrient enter into the soil system (input) and leaving the system (output), and provide information about environmental pressures. Nutrient input and apparent nutrient balance were presented in Tables 4 and $A 6$.

Table 4. Annual nutrients uptake and apparent nutrient balance $(N, P$, and $K)$ and crop yield in maize-spring wheat and winter wheat cropping system from the period of (1990-2010) and (2000-2010) under different fertilization of long-term experiment over 20 years of fertilization

\begin{tabular}{|c|c|c|c|c|c|c|c|c|}
\hline Years & Treatments & $\begin{array}{c}\mathrm{NU} \\
\left(\mathrm{kg} \mathrm{ha}^{-1}\right)\end{array}$ & $\begin{array}{c}\mathrm{PU} \\
\left(\mathrm{kg} \mathrm{ha}^{-1}\right)\end{array}$ & $\begin{array}{c}\mathrm{KU} \\
\left(\mathrm{kg} \mathrm{ha}^{-1}\right)\end{array}$ & $\begin{array}{c}\text { N balance } \\
\left(\mathrm{kg} \mathrm{ha}^{-1} \text { year }^{-1}\right)\end{array}$ & $\begin{array}{c}\text { P balance } \\
\left(\mathrm{kg} \mathrm{ha}^{-1} \text { year }^{-1}\right)\end{array}$ & $\begin{array}{c}\text { K balance } \\
\left(\mathrm{kg} \mathrm{ha}^{-1} \text { year }^{-1}\right)\end{array}$ & $\begin{array}{c}\text { Grain yield } \\
\left(\mathrm{t} \mathrm{ha}^{-1}\right)\end{array}$ \\
\hline \multirow{5}{*}{$\begin{array}{l}\text { 1990-2000 } \\
\text { Maize }\end{array}$} & CK & 76.05 & 7.11 & 0.00 & -3.72 & -7.11 & 0.00 & 4.41 \\
\hline & NPK & 136.75 & 15.57 & 0.00 & 78.58 & 46.43 & 48.13 & 5.76 \\
\hline & NPKM & 128.94 & 23.11 & 0.00 & 166.06 & 40.23 & 209.11 & 6.66 \\
\hline & NPKS & 134.03 & 15.61 & 0.00 & 82.97 & 36.95 & 42.32 & 6.53 \\
\hline & NPKM2 & 134.61 & 24.26 & 0.00 & 435.39 & 97.04 & 413.23 & 6.41 \\
\hline \multirow{5}{*}{ Spring wheat } & CK & 21.59 & 2.73 & 4.65 & -12.24 & -0.94 & 4.65 & 1.02 \\
\hline & NPK & 89.40 & 13.11 & 24.33 & 131.32 & 38.89 & 56.41 & 2.95 \\
\hline & NPKM & 106.33 & 18.13 & 35.81 & 171.23 & 39.07 & 175.21 & 3.82 \\
\hline & NPKS & 86.19 & 12.75 & 26.07 & 139.67 & 36.68 & 54.28 & 2.63 \\
\hline & NPKM2 & 102.12 & 18.20 & 27.86 & 347.95 & 77.70 & 303.35 & 3.23 \\
\hline \multirow{5}{*}{ Winter wheat } & CK & 34.62 & 3.93 & 2.13 & -34.62 & -3.93 & -2.13 & 1.28 \\
\hline & NPK & 139.19 & 19.11 & 17.56 & 101.81 & 42.89 & 30.57 & 4.46 \\
\hline & NPKM & 125.42 & 22.78 & 17.75 & 169.58 & 40.57 & 191.35 & 4.96 \\
\hline & NPKS & 88.76 & 18.40 & 17.28 & 128.24 & 34.17 & 25.04 & 4.29 \\
\hline & NPKM2 & 126.48 & 26.34 & 20.99 & 463.30 & 99.48 & 413.23 & 5.40 \\
\hline \multirow{5}{*}{$\begin{array}{l}\text { 2000-2010 } \\
\text { Maize }\end{array}$} & CK & 61.10 & 8.00 & 134.57 & -61.10 & -8.00 & -134.57 & 3.22 \\
\hline & NPK & 168.89 & 30.68 & 273.93 & 72.11 & 31.32 & -225.80 & 7.73 \\
\hline & NPKM & 176.26 & 29.17 & 312.12 & 118.74 & 34.18 & -103.01 & 8.58 \\
\hline & NPKS & 178.35 & 32.22 & 317.81 & 38.65 & 20.34 & -275.49 & 8.57 \\
\hline & NPKM2 & 200.96 & 43.53 & 337.26 & 369.04 & 77.77 & 75.97 & 9.01 \\
\hline \multirow{5}{*}{ Spring wheat } & CK & 35.36 & 4.93 & 29.71 & -35.36 & -4.93 & -29.71 & 0.69 \\
\hline & NPK & 155.12 & 17.00 & 110.62 & 85.88 & 45.00 & -62.49 & 2.85 \\
\hline & NPKM & 150.82 & 21.38 & 158.23 & 144.18 & 41.97 & 50.88 & 3.39 \\
\hline & NPKS & 136.72 & 18.96 & 120.42 & 80.28 & 33.60 & -78.11 & 3.08 \\
\hline & NPKM2 & 195.84 & 23.97 & 165.25 & 374.16 & 97.33 & 247.99 & 3.42 \\
\hline \multirow{5}{*}{ Winter wheat } & CK & 18.58 & 7.75 & 7.61 & -18.58 & -7.75 & -7.61 & 1.02 \\
\hline & NPK & 125.07 & 43.71 & 74.38 & 115.93 & 18.29 & -26.25 & 5.52 \\
\hline & NPKM & 139.33 & 54.15 & 87.00 & 155.67 & 9.19 & 122.11 & 6.02 \\
\hline & NPKS & 89.68 & 34.93 & 49.86 & 127.32 & 17.64 & -7.54 & 4.35 \\
\hline & NPKM2 & 153.90 & 54.80 & 77.00 & 416.10 & 66.50 & 336.24 & 6.58 \\
\hline
\end{tabular}


Among all the fertilization years (1990-2010), in all treatments the highest nutrient uptake (nitrogen, phosphorous, and potassium) were observed in NPKM2 and the lowest was in CK. Among all the crops the nitrogen uptake (NU) showed a decrease in the year of fertilization from 1990-2010 in NPKM, NPKS, NPKM2 while increased from 2000 to 2010. Phosphorus and potassium uptake also showed the same trend as NU uptake, the highest nutrient uptake was in NPKM2 among all the fertilization years. A minor change was observed among the control treatment in all crops. The apparent nutrient balance was significantly different from control as compared to treatments. The control showed a negative value and a deficit in nutrient balance among the crop from 1990-2010. The nitrogen, phosphorus, and potassium showed a positive value and surplus nutrient balance was showed in NPKM2 and significantly different from other treatments. Nitrogen and phosphorous balance among all treatments were positive during all the cropping periods. The potassium balance showed a negative value for all the treatments except NPKM2 and NPKM during all cropping periods except from 2000-2010 the NPKM showed negative value in the maize and winter wheat cropping system. The potassium balance in maize ranges from $77.77 \mathrm{~kg} \mathrm{ha}^{-1} \mathrm{year}^{-1}$ in NPKM to $8.00 \mathrm{~kg} \mathrm{ha}^{-1}$ year ${ }^{-1}$, in Spring wheat $247.99 \mathrm{~kg} \mathrm{ha}^{-1}$ year $^{-1}$ to $-29.79 \mathrm{~kg} \mathrm{ha}^{-1}$ year $^{-1}$ while in winter wheat $247.99 \mathrm{~kg} \mathrm{ha}^{-1}$ year $^{-1}$ to $-7.61 \mathrm{~kg} \mathrm{ha}^{-1}$ year ${ }^{-1}$. The nutrient balance over 20 years of fertilization in nitrogen and phosphorous showed a decreasing trend among all the treatments in 2000-2010 as compared to 1990-2000.

\section{Dynamics of soil nutrients and soil organic carbon sequestration rate (CSR)}

The soil $\mathrm{pH}$, nutrients, and soil organic carbon sequestration were significantly influenced by long-term fertilization. During the two long-term fertilization periods 1990-2000 and 2000-2010, the soil pH fluctuated from 8.12 in NPK and 8.40 in NPKS. Soil $\mathrm{pH}$ increased in the second period of soil fertilization as compared to the first year 1990-2000 (Table 5). Soil TN, TP, and TK in the maize cropping system showed an increasing trend in NPKM2 followed by NPKM, NPK, and NPKS in the fertilization year of 1990-2000 while the same trend was followed by the second year of fertilization with minor variation. All the nutrients showed an increasing trend while AK showed decreasing values during the years of fertilization. In the cropping system of spring wheat, the TN, TP, and AN, AP and AK showed a higher value in NPKM2 followed by NPKM, NPK, and NPKS respectively in the fertilization period 1990-2000. The comparison of two periods of fertilization showed that all the nutrients decreased in the second year of fertilization except NPK and NPKS in TN, NPKM in TP, NPK, and NPKM in AN and NPKM in AP respectively. In the winter wheat cropping system the TN, TP, and AN, AP, and AK showed a higher value in NPKM2, NPKM and NPKS and NPK, respectively. The NPKM indicated an increasing trend when compared with the initial year of fertilization while all other nutrients decreased in the second year of fertilization (2000-2010). The combined application of synthetic fertilizer and organic fertilizer (sheep manure) significantly increases the soil nutrient level among all treatments such as available and total nitrogen, available and total phosphorous, and total potassium. Manure increases soil fertility and also soil structure and it significantly increases the nutrient input to the soil system. Soil organic carbon in the maize cropping system showed a positive relationship in the year of fertilization and increased with time, higher SOC was observed in NPKM2 followed by NPKM. The highest OC g kg-1 was found in NPKM2 followed by NPKM, NPK, and NPKS and control. The RY tha ${ }^{-1}$ also followed the same trend. The spring wheat showed the highest value of $\mathrm{OC} \mathrm{g} \mathrm{kg}^{-1}$ 
in NPKM followed by NPKM, NPKS, and NPK, the lowest was found in control treatment among all the cropping systems in fertilization years. The RY also had the same trend of increasing value. In winter wheat $\mathrm{OC} \mathrm{g} \mathrm{kg}^{-1}$ showed a higher value in the soil NPKS with the minute increase from NPKM2 in both years of fertilization and a similar trend was followed in both years with little increase. The soil carbon change was shown in Table A6 and Figure A1. The RY t ha ${ }^{-1}$ was higher in NPKM2 followed by NPKM and NPKS. Soil carbon sequestration rate (CSR t ha ${ }^{-1} \mathrm{yr}^{-1}$ ) showed negative value among all the CK, NPKM, and NPKS while it showed positive value for both NPKM and NPK. Overall, the change in all fertilization treatments was no sign of CSR.

Table 5. Soil nutrient contents, annual organic carbon, and soil organic sequestration rate CSR in maize-winter/spring wheat cropping system form the period of 1990-2010 under different fertilization treatments in long term experimental site

\begin{tabular}{|c|c|c|c|c|c|c|c|c|c|c|}
\hline Year/crop & Treatments & $\underset{\left(\mathrm{g} \mathrm{kg}^{-1}\right)}{\mathbf{T N}}$ & $\underset{\left(\mathrm{g} \mathrm{kg}^{-1}\right)}{\mathbf{T P}}$ & $\underset{(\mathbf{m g ~ k g}}{\mathbf{A N}}$ & $\underset{\left(\mathbf{m g ~ k g}^{-1}\right)}{\mathbf{A P}}$ & $\underset{\left(\mathbf{m g ~ k g}^{-1}\right)}{\mathbf{A K}}$ & $\underset{\left(\mathrm{g} \mathrm{kg}^{-1}\right)}{\mathrm{OC}}$ & pH & $\begin{array}{c}\mathbf{R Y} \\
\left(\mathrm{t} \mathbf{h a}^{-1}\right)\end{array}$ & $\begin{array}{c}\text { CSR } \\
\left(\mathrm{t} \mathrm{ha}^{-1} \mathbf{y}^{-1}\right)\end{array}$ \\
\hline Initial year & & 1.01 & 0.35 & 84.6 & 9 & 461 & 9.78 & 8.01 & - & - \\
\hline \multirow{5}{*}{$\begin{array}{c}\text { 1990-2000 } \\
\text { Maize }\end{array}$} & CK & 0.98 & 0.69 & 56.20 & 2.73 & 144.00 & 8.48 & 8.30 & 1.28 & -0.116 \\
\hline & NPK & 0.98 & 0.79 & 53.07 & 10.53 & 135.00 & 9.32 & 8.12 & 4.46 & 0.000 \\
\hline & NPKM & 1.12 & 0.77 & 67.77 & 12.27 & 335.33 & 10.16 & 8.28 & 4.96 & 0.000 \\
\hline & NPKS & 0.95 & 0.61 & 54.80 & 7.73 & 160.83 & 8.63 & 8.40 & 4.29 & 0.000 \\
\hline & NPKM2 & 1.15 & 0.82 & 73.30 & 32.03 & 351.67 & 11.94 & 8.21 & 5.40 & -0.001 \\
\hline \multirow{5}{*}{$2000-2010$} & CK & 0.68 & 0.60 & 45.77 & 4.06 & 165.67 & 7.98 & 8.40 & 1.02 & -0.051 \\
\hline & NPK & 0.92 & 0.91 & 62.83 & 13.00 & 219.73 & 9.05 & 8.50 & 5.52 & 0.001 \\
\hline & NPKM & 1.47 & 0.80 & 99.37 & 50.70 & 390.07 & 11.37 & 8.29 & 6.02 & 0.000 \\
\hline & NPKS & 0.70 & 0.63 & 54.63 & 8.57 & 124.87 & 8.57 & 8.28 & 4.35 & -0.002 \\
\hline & NPKM2 & 1.21 & 0.77 & 81.90 & 30.70 & 391.83 & 14.10 & 8.40 & 6.58 & -0.002 \\
\hline \multirow{5}{*}{$\begin{array}{c}1990-2000 \\
\text { Spring wheat }\end{array}$} & CK & 0.80 & 0.50 & 52.50 & 2.13 & 129.80 & 8.41 & 8.35 & 1.02 & -0.1232 \\
\hline & NPK & 0.89 & 0.83 & 54.67 & 13.23 & 194.07 & 8.78 & 8.11 & 2.95 & 0.0004 \\
\hline & NPKM & 1.17 & 0.75 & 71.20 & 18.77 & 351.20 & 8.86 & 8.32 & 3.82 & 0.0002 \\
\hline & NPKS & 0.86 & 0.70 & 54.37 & 8.67 & 160.83 & 9.63 & 8.36 & 2.63 & -0.0001 \\
\hline & NPKM2 & 1.40 & 0.98 & 84.70 & 37.30 & 413.90 & 10.98 & 8.23 & 3.23 & -0.0013 \\
\hline \multirow{5}{*}{$2000-2010$} & CK & 0.73 & 0.55 & 38.75 & 2.87 & 153.50 & 7.86 & 8.41 & 0.69 & -0.076 \\
\hline & NPK & 0.96 & 0.79 & 56.25 & 14.95 & 185.00 & 8.76 & 8.29 & 2.85 & 0.000 \\
\hline & NPKM & 0.96 & 0.73 & 86.25 & 29.55 & 325.50 & 8.14 & 8.28 & 3.39 & 0.000 \\
\hline & NPKS & 1.17 & 0.66 & 51.55 & 16.30 & 157.50 & 9.84 & 8.40 & 3.08 & -0.003 \\
\hline & NPKM2 & 1.20 & 0.68 & 71.45 & 23.60 & 314.50 & 10.60 & 8.42 & 3.42 & 0.000 \\
\hline \multirow{5}{*}{$\begin{array}{c}1990-2000 \\
\text { Winter wheat }\end{array}$} & CK & 0.85 & 0.70 & 48.65 & 3.65 & 172.08 & 7.96 & 8.40 & 4.41 & -0.097 \\
\hline & NPK & 0.92 & 0.95 & 74.10 & 10.63 & 148.75 & 8.69 & 8.26 & 5.76 & 0.000 \\
\hline & NPKM & 1.19 & 0.76 & 75.88 & 12.73 & 385.75 & 10.93 & 8.28 & 6.66 & 0.000 \\
\hline & NPKS & 0.94 & 0.74 & 69.23 & 7.95 & 205.63 & 8.53 & 8.40 & 6.53 & -0.001 \\
\hline & NPKM2 & 1.44 & 0.88 & 94.53 & 33.30 & 374.75 & 12.88 & 8.24 & 6.41 & -0.002 \\
\hline \multirow{5}{*}{$2000-2010$} & CK & 0.72 & 0.67 & 50.17 & 3.39 & 125.33 & 7.87 & 8.42 & 3.22 & -0.064 \\
\hline & NPK & 0.81 & 0.87 & 57.47 & 11.40 & 290.00 & 8.52 & 8.29 & 7.73 & 0.001 \\
\hline & NPKM & 1.41 & 0.89 & 92.63 & 52.00 & 583.33 & 11.24 & 8.28 & 8.58 & 0.000 \\
\hline & NPKS & 0.72 & 0.71 & 79.53 & 10.63 & 180.67 & 8.22 & 8.40 & 8.57 & -0.002 \\
\hline & NPKM2 & 1.14 & 0.67 & 70.03 & 20.71 & 375.00 & 12.71 & 8.38 & 9.01 & -0.003 \\
\hline
\end{tabular}

Means followed by an average of ten years' data in which every year data with different crop means considered separately for maize, spring wheat, and winter wheat, values of means are $(\mathrm{n}=3)$. Abbreviations: TN, total N; TP, total P; AN, available N; AP, Available P; RY, Relative Yield; CSR, soil carbon sequestration rate 


\section{Principal component analysis (PCA)}

The Principal Component Analysis (PCA) clustering processes are usually performed to measure the variation among the treatment effect and show the relationship between the variables. It interprets the data more expressively than other tools. There are two components in the principal component analysis as PC1 and PC2. The PCA analysis was performed to check the variation effect among the treatments on different variables such as (NU, PU, KU, N balance, $\mathrm{P}$ balance, $\mathrm{K}$ balance, and grain yield) over the year of fertilization from 1990-2000 and 2000-2010. The principal component analysis from the year of fertilization 1900-2000 among different variables (Fig. 4a) showed that all the values were more diverse and showed variation over different treatments. The first PC1 and second PC2 together described 87.3 of the total variation among all the observed values. The principal component analysis (PC1) (Figure 4) variation primarily attributes to NU, PU, KU, N bal, P bal, K bal, and GY for which eigenvectors were $4.65,1.45,0.66,0.122,0.051,0.038$, and 0.004 , respectively.

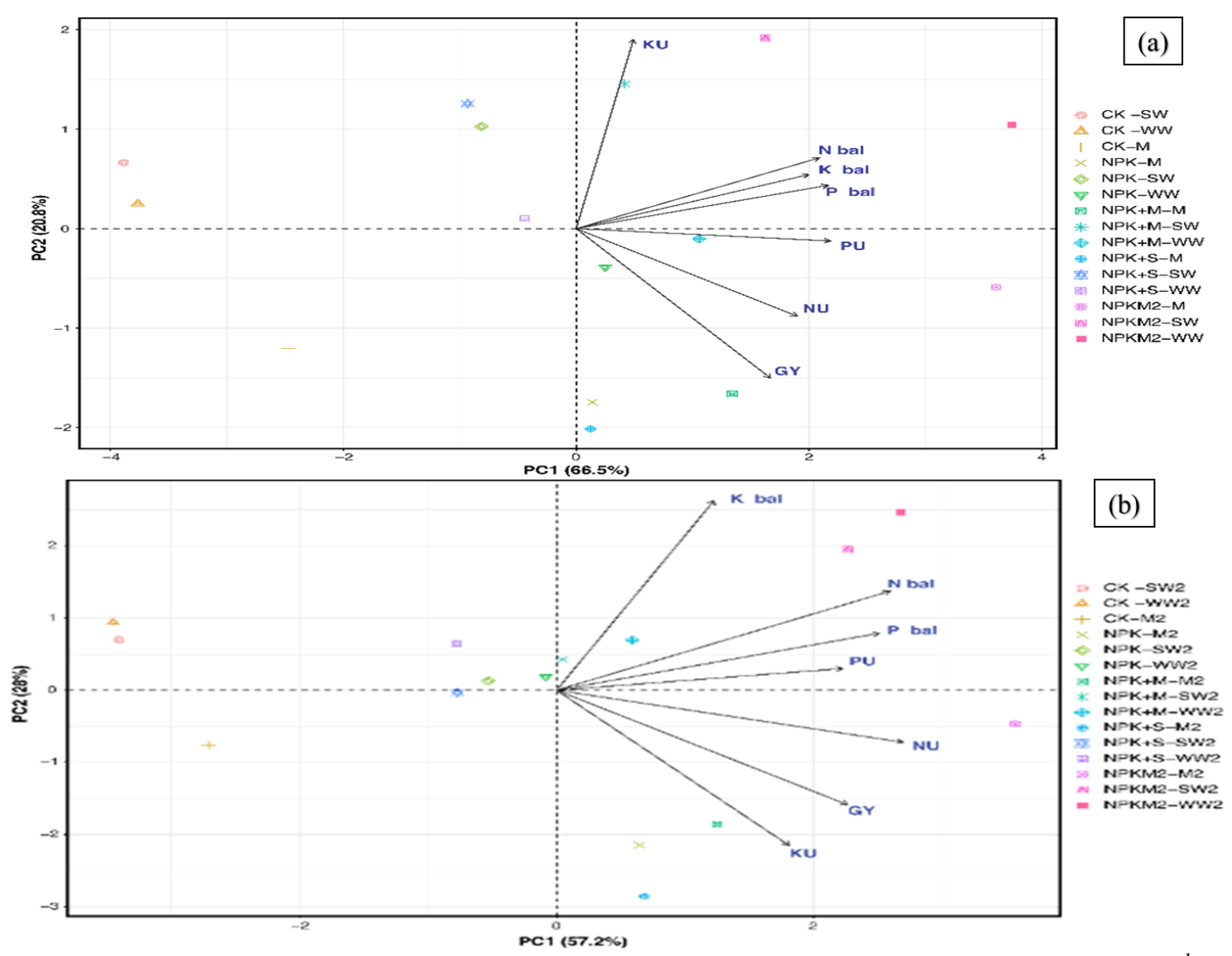

Figure 4. Principal component analysis (PCA) (a) (1990-2000) of nutrient Uptake ( $\mathrm{kg} \mathrm{ha}^{-1}$ Year $\left.^{-1}\right)(N U, P U$, and $K U)$ and nutrient balance $\left(\left(\mathrm{kg} \mathrm{ha}^{-1}\right.\right.$ Year $\left.\left.^{-1}\right)\right)$ representing through $\mathrm{N}$ bal (nitrogen balance); $P$ bal (Phosphorous balance) and $K$ bal (potassium balance) and GY (grain yield $\left.\left(t h a^{-1}\right)\right)$ while PC: principal component. (b) Principal component analysis (PCA) on the years from 2000-2010. Every point on the scatter plot showed the effect of a single treatment on nutrients. Control (CK) and NPK of maize, spring wheat and winter wheat showed less variation on nutrient uptake, balance, and grain yield while higher variation was showed by treatment NPKM2 followed by NPKM and NPKS respectively 
The second figure (Fig. 4b) of PCA showed the variation among the nutrient uptake, balance, and grain yield for the year of fertilization 2000-2010. The PC1 and PC2 contribute 85.2 of variation in treatment effect from the 2000-2010 fertilization year. The variation in PC1 is attributed to NU, PU, KU, N bal, P bal, K bal, and GY with eigenvector of $4.00,1.96,0.81,0.15,0.04,0.008$, and 0.003 , respectively. The treatment effect on the different years of fertilization was shown in Figure 4, and variation among the different years was observed in both graphs of PCA. The control, NPK, NPKM, NPKS, and NPKM2 showed a significant effect on the nutrient uptake and balance under the different treatments over 20 years. The different nutrient poses major attribute and influence on the yield of the crop. Moreover, the correlation was positive among all the nutrient uptake, balance, and grain yield. The treatments having a combined application of organic and inorganic fertilizer showed higher yield and it improved the soil fertility and crop yield.

\section{Correlation of nutrient uptake, nutrient balance, and grain yield.}

Pearson's correlation analysis is the best tool for complex data visualizing. Pearson's correlation analysis was performed to study nutrient uptake, nutrient balance, and grain yield throughout the 20 years. The different nutrient uptake balances showed a positive relationship among the nutrient uptake by crop and grain yield (Fig. 5).

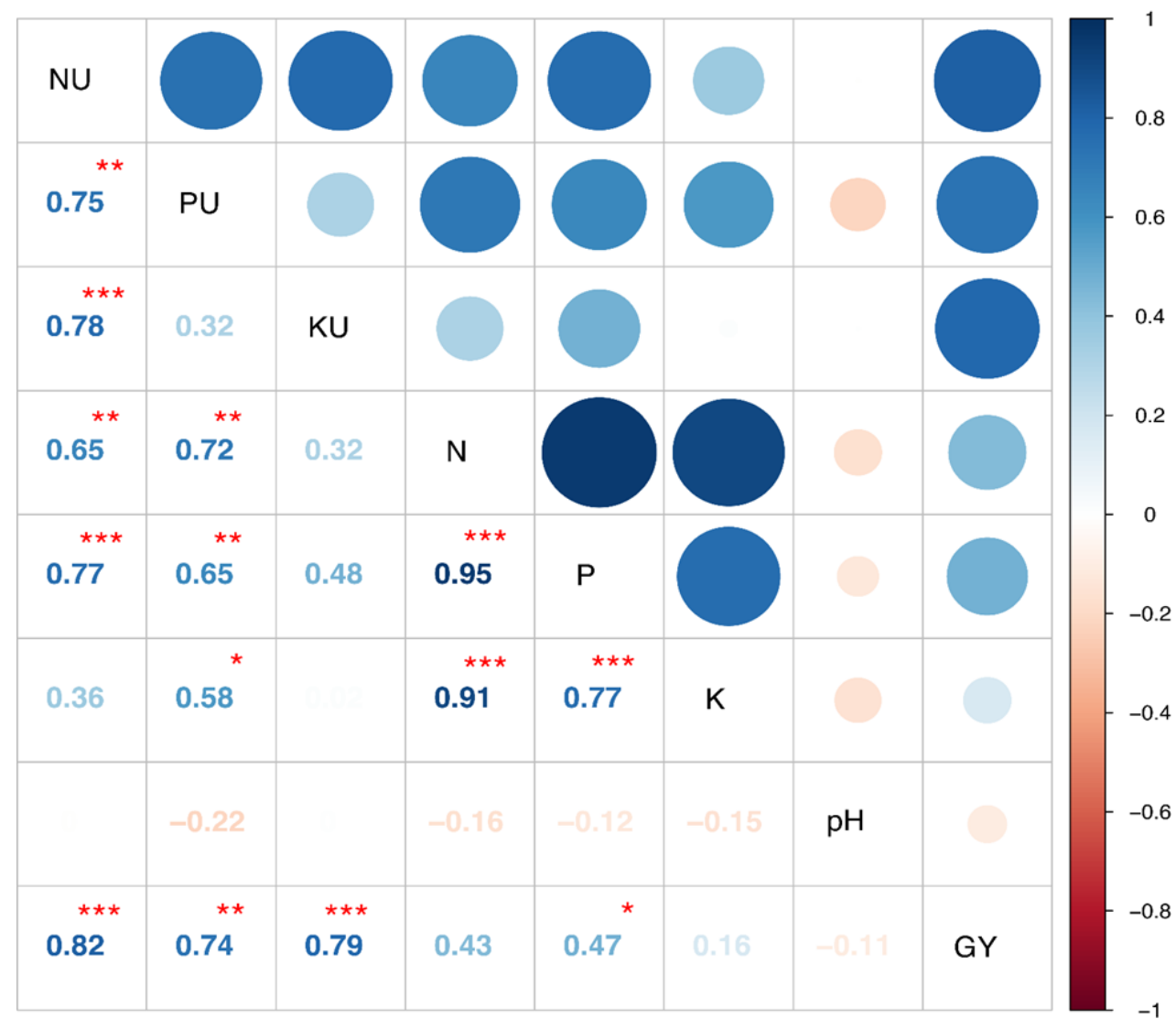

Figure 5. The correlation analysis between the nutrient uptake, nutrient balance, $p H$, and grain yield. The above diagonal characterizes the coefficient correlation of the p-value $p<0.05,0.01$, and 0.001; denote significance at *, **, and *** correspondingly. The lower plot of diagonal showed NU, Nitrogen uptake; $P U$, phosphorus uptake; KU, Potassium uptake; $N$ balance; $P$ balance; $K$ balance $\left(\mathrm{kg} \mathrm{ha}^{-1}\right), \mathrm{pH}$ and grain yield $\left(\mathrm{t} \mathrm{ha^{-1 } )}\right.$ 
Grain yield showed a positive relationship with nutrient uptake of $\mathrm{N}, \mathrm{P}$, and $\mathrm{K}$, the correlation was positive, it represented that it had a significant effect on nutrient uptake and showed positive correlation with nutrient balance PU followed by NU respectively. The grain yield showed a highly significant correlation with $\mathrm{NU}(\mathrm{r}=0.82 * * *)$ followed by $\mathrm{KU}\left(\mathrm{r}=0.79^{* *}\right)$ and $\mathrm{PU}\left(\mathrm{r}=0.74^{* *}\right)$ while $\mathrm{pH}$ had a negative effect on it. Nutrient balance showed highly significant effect on each other and showed a positive relationship with each other. The $\mathrm{N}$ balance showed highly positive correlation with $\mathrm{P}$ balance $\left(\mathrm{r}=0.95^{* * *}\right)$ followed by $\mathrm{K}$ balance $(\mathrm{r}=0.91 * * *)$. $\mathrm{N}$ nutrient uptake showed a positive correlation with $\mathrm{k}$ uptake $\left(\mathrm{r}=0.78^{* * *}\right)$ and $\mathrm{P}$ uptake $\left(\mathrm{r}=0.75^{* * *}\right)$. The $\mathrm{pH}$ had a negative effect on all the nutrient uptake and balance and showed a negative relationship with each other.

\section{APSIM results on climatic change and nitrogen model}

Agricultural Production System Simulator (APSIM) well simulated the climatic change and nitrogen model in wheat-maize cropping system in Urumqi China. The APSIM showed significant results on the climatic change model of the current weather condition. The precipitation over the years of fertilization showed variations throughout the years. The runoff showed a positive relationship with the precipitation. The higher the precipitation, the higher the runoff, and the higher the nutrient losses from the soil system. The surface runoff and leaching normally occur with rainfall events. This leads to the environmental risk of phosphorus transportation from agroecosystems to rivers and lakes. Hence it was proved from the overall nutrient balance (Table 4) that the highest phosphorous balance was observed in NPKM2 and NPKM. So APSIM also showed surface runoff with precipitation, moreover, the rates of $\mathrm{P}$ inputs should be reduced to prevent the nutrient losses in to soil, air and water environment. This will lead to the achievement of sustainable crop production and decreasing environmental pollution risk (Fig. 8). The soil hydrodynamic properties among each layer of the soil were measured through APSIM through saturated water content (SAT) and field water holding capacity (DUL), SAT was calculated from soil bulk density. It gives complete changes in soil dynamics of different nutrients. In this current study, we used eight layers up to $160 \mathrm{~cm}$ showed in Table A2. The soil hydrodynamic was shown in Figure $6 a, b$. There are two major crops such as maize and wheat. The crop and soil parameters were the crop's lower limit (LL) and the crop water absorption coefficient (KL) at 8 different layers and depths. The LL and KL were also calculated separately for maize and wheat crops. There were no values based on which we measure but it is adjusted and estimated based on APSIM software. The effect of water balance runoff, drainage, and esw (essential soil water) was affected by soil water capacity and weather. The climatic change model showed a significant change in nitrogen balance throughout 20 years (Figs. 7 and 8; Table A4). The runoff ( $\mathrm{mm})$, esw (mm), leaching (0-1), total $\mathrm{NO}_{3}{ }^{-}\left(\mathrm{kg} \mathrm{ha}^{-1}\right)$, and total $\mathrm{NH}_{4}{ }^{+}\left(\mathrm{kg} \mathrm{ha}^{-1}\right)$ and precipitation showed significant results with both $\mathrm{CO}_{2}$ levels (350-650) ppm. The observed and predicted graph with linear regression showed significant changes when the climatic model was applied. The level of $\mathrm{CO}_{2}$ from $350 \mathrm{ppm}$ to $650 \mathrm{ppm}$ was changed and precipitation was changed to -10 and maximum and minimum temperature was changed to $+2{ }^{\circ} \mathrm{C}$. The average precipitation over 20 years of simulation received was $0.63 \mathrm{~mm}$ in observed while in predicted $0.57 \mathrm{~mm}$. The runoff was changed from $0.43 \mathrm{~mm}$ to $0.40 \mathrm{~mm}$. The change observed in total $\mathrm{NO}_{3}{ }^{-}$(1444.0 to 1422.5$) \mathrm{kg} \mathrm{ha}^{-1}$ and total $\mathrm{NH}_{4}{ }^{+}$(35.1 to 41.72) $\mathrm{kg} \mathrm{ha}^{-1}$ respectively. Leaching defined as the loss of water-soluble plant nutrients due to 


$$
\text { - } 1841 \text { - }
$$

precipitation and irrigation from the soil. Leaching fraction is the $\mathrm{LF}=$ effluent / influent. The nitrogen leaching was observed between (0.75-0.73) and no change in the drainage was observed. Nitrogen balance $\left(\mathrm{kg} \mathrm{ha}^{-1}\right)$ was 14.38-19.22 and essential soil water (esw (mm)) was 191.2-181.1. The changes in the climatic model showed that the change in future environmental parameters had a significant effect on soil, crop, and water parameters (Table A4). Proper measurements are needed to be taken to overcome the significant changes in the environment and increase crop production and improve soil fertility.

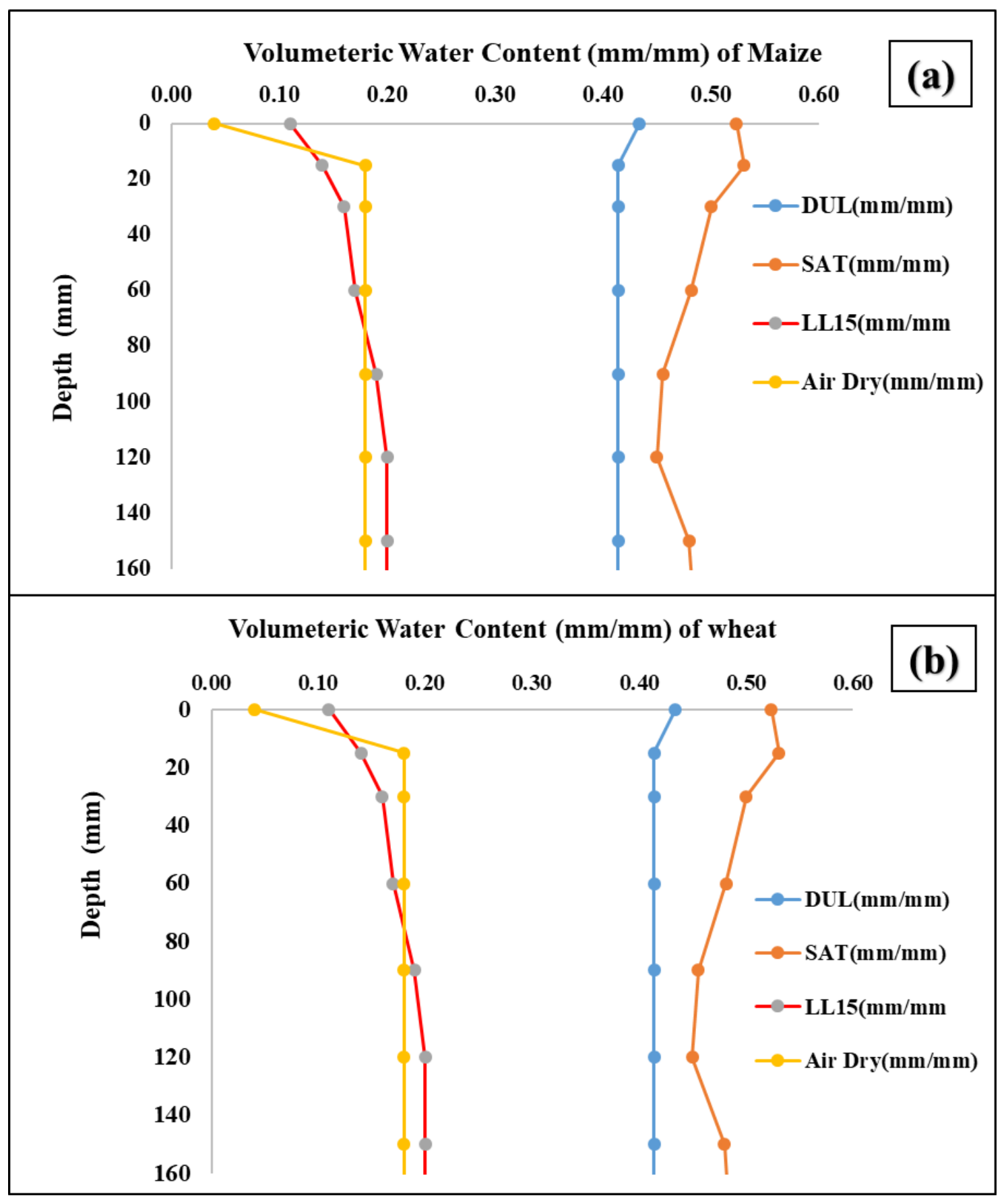

Figure 6. Volumetric water content under different layers (1-160) divided into 8 different layers. (a) Maize crop and (b) wheat crop 

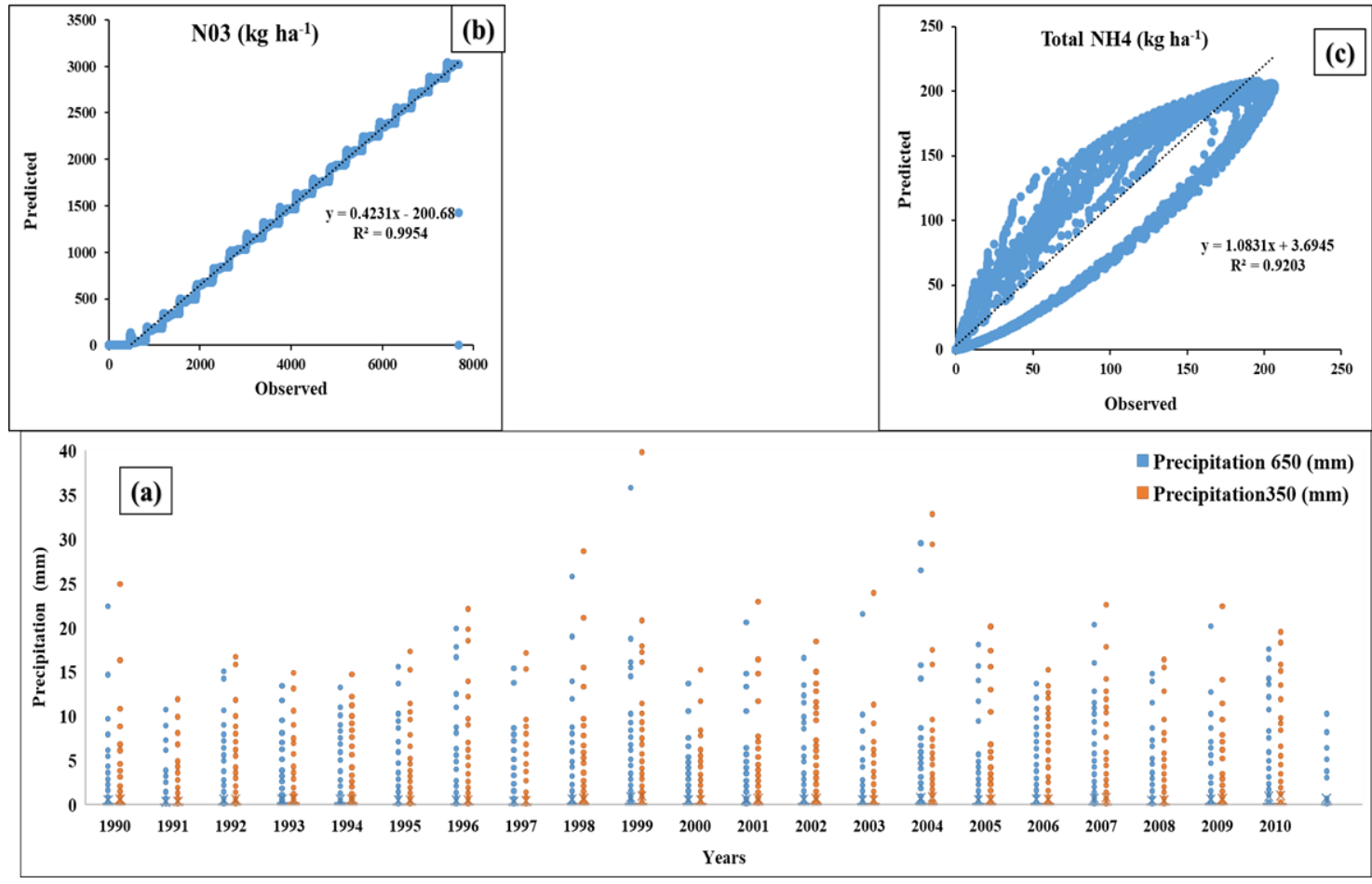

Figure 7. The graph was created through APSIM climatic change and nitrogen model with 305 ppm and 650 ppm scenario of $\mathrm{CO}_{2}$ and change in temperature (Maximum and minimum) $(+2)$ and precipitation (-10). (a) Years vs precipitation $(\mathrm{mm})$ during climatic model when precipitation was change to (-10) on 20 years' simulation. (b) $\mathrm{NO}_{3}^{-}\left(\mathrm{kg} \mathrm{ha}^{-1}\right)$ during observed and simulated values. (c) $\mathrm{NH}_{4}{ }^{+}$leaching observed and simulated and trend lines showed relationship
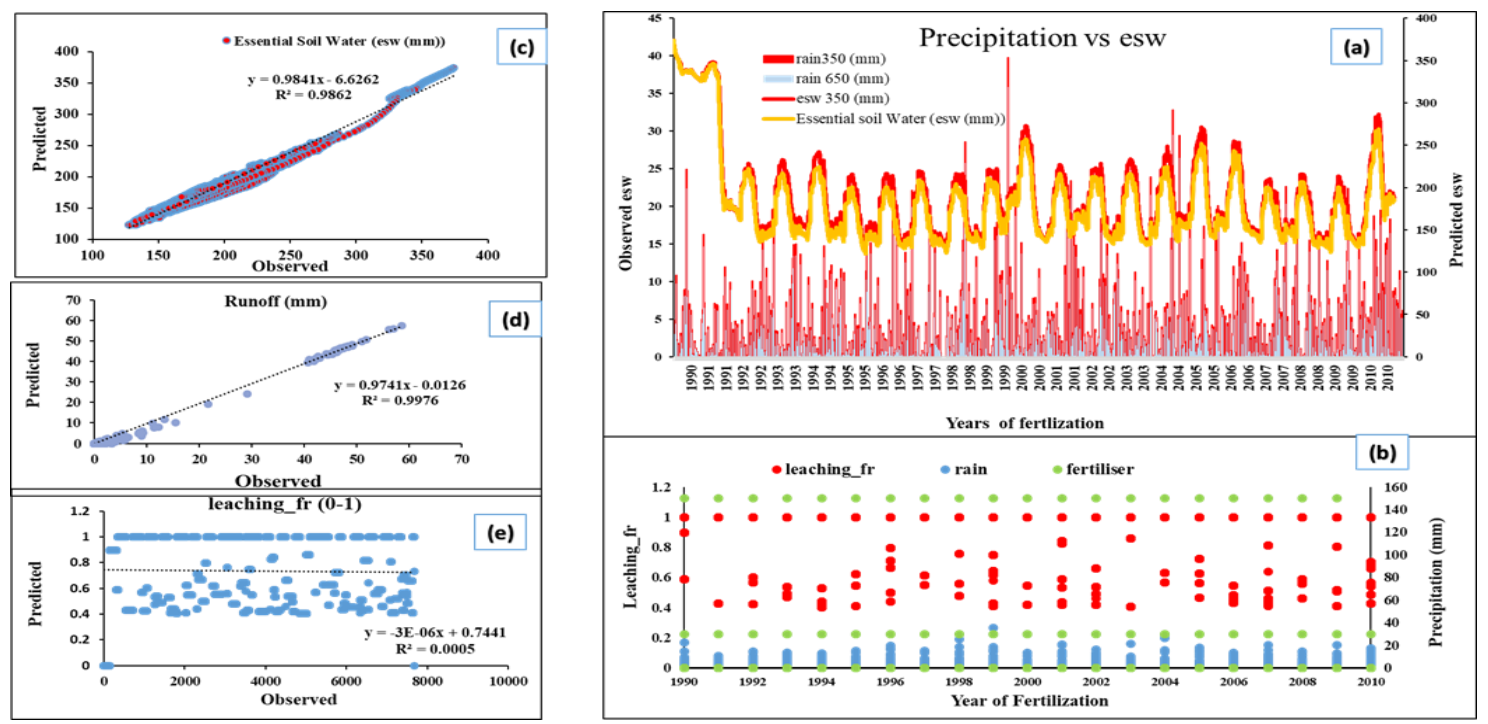

Figure 8. (a) Precipitation vs essential soil water (esw) over fertilization years 1990-2010 (b) years of fertilization vs leaching and rain fall. (c) Essential soil water (esw) ( $\mathrm{mm}$ ) observed vs predicted $(d)$ Total runoff $(\mathrm{mm})$ during observed and predicted simulation, and $(e)$ leaching $(0-$ 1) observed vs predicted over the 20 years of fertilization 


\section{Discussion}

In our findings it was clearly showed that over 20 years of fertilization, the combined application of inorganic and organic (sheep manure) significantly enhanced crop growth, yield, and soil fertility as compared to a single application of organic fertilizer. Crop yields of CK (control) among all crops (maize, spring wheat, and winter wheat) showed a decrease over the years of fertilization. The grain yield in all treatments increased in NPKM2, NPKM, NPKS, and NPK over the years (1990-2010) (Table 4; Fig. 3) (Das et al., 2014). Manure is reported to be used to effectively improve the agricultural fertility of the soil and soil health (Gai et al., 2018). The long-term fertilization treatments of grain yield during organic manure treatments may be attributed to the enhanced availability of a reservoir of organic minerals by applying manure to the soil. Long-term fertilizer application and organic manure significantly enhanced deposition of soil organic carbon as well as nitrogen and also microbial soil biomass, obtaining maximum SMBC consisting of $3.7 \%$ of SOC, SMBN accounted for $4.5 \%$ of total nitrogen, and SMBP contributed for $2.1 \%$ of total phosphorous. These soil organic carbon and nitrogen deposits were effective in slowing the decomposition of inborn soil carbon (Qiu et al., 2018). Our result was supported by the previous finding, the use of such synthetic and organic (manures) fertilizers improved significantly yield and quality of wheat, maize, and rice by an overall gain of only $29 \%$ compared to other organic fertilizers and by $8 \%$ compared to the synthetic fertilizer application (Han et al., 2004). The previous results showed that the positive residual impacts on agricultural productivity were observed in various long-term fertilization dynamics (Chavas et al., 2009; La et al., 2016). The key reasons for reduced agricultural productivity in CK and NPK may be soil acidification, as constant use of synthetic fertilizers tends to decrease soil productivity by reducing soil $\mathrm{pH}$ and has a higher influence on $\mathrm{CO}_{2}$ fixation and soil microbial growth (Sarkar et al., 2018). In previous studies a high reduction of crop yield was observed under chemical fertilization in paddy soils over the time (Yang et al., 2018). The result of (Zhu et al., 2018) suggested that to reduce soil acidification high chemical nitrogen fertilization can be partially supplemented by composite or natural fertilizer in tea crop (Zhang et al., 2010, 2018). The organic and inorganic fertilizer application increased nitrogen, phosphorous, and potassium as compared to CK and NPK shown in Table 4, which were also similar to the findings of (Wei et al. 2020) and Yang et al., 2020). With the combined application of organic and synthetic fertilizer, we found that the nutrient balance was positive and the highest in NPKM2 followed by NPKM, NPKS, and NPK. The CK showed a negative balance among all the crops showed in Table 4. The result was similar to the finding of (Hu et al., 2019) who stated that the amount of crop production, grain yield, and nitrogen was high when organic and inorganic fertilizers were used as treatment. The nitrogen use effectiveness was also high in manure. The yield and nutrients were balanced under these treatments. The manure treatment showed higher results as compared to other treatments among all the crops over 20 years of fertilization showed in Table 4 and 5, similar findings were showed in organic and inorganic fertilizer treatments (NPKM and NPKM2) the activities of the enzymes were enhanced and it is the reason of soil nutrients increase and the soil pH was not change (Zhang et al., 2019). The soil nutrient balance of nitrogen and phosphorus was high in the years 1990-2000 as compared to 2000-2010. The nutrient balance was high in NPKM2 followed by NPKM, NPKS, and NPKM over the years of fertilization. The correlation in Figure 5 also showed a positive correlation among NU, PU, and $\mathrm{N}$ balance and $\mathrm{P}$ balance. The positive $\mathrm{N}$ and $\mathrm{P}$ balance was due to 
lower $\mathrm{N}$ uptake by crops. Previous studies indicated that nitrogen effectiveness of nutrient usages (NUE) and improper fertilization significantly reduced nitrogen uptake (NU) and increased nutrient balance and nutrient depletion in the soil (Shi et al., 2012; Egan et al., 2019). The analysis indicates that long-term organic fertilizer has the most positive effects on grain yield and soil fertility (Liu et al., 2010). Various research studies showed that the soil properties (physical and chemical) were significantly affected by organic matter addition (Liu et al., 2010). The study of maize-spring wheatwinter wheat in the Urumqi region showed that the addition of organic manure with synthetic fertilizer enhanced crop yield and nutrient availability in increasing trend and significant change was observed in NPKM2 and NPKM as shown in Figure 3 and Table 4. Similar increasing findings were also experienced by (Wei et al., 2015, 2020). Soil organic carbon increased in the combined treatments NPKM2 followed by NPKM (Table A6). The minor change was experienced in syntactic fertilizer application alone NPKS and NPK while significantly decrease in CK from $9.8 \mathrm{~g} \mathrm{~kg}^{-1}$ to $7.8 \mathrm{~g} \mathrm{~kg}^{-1}$ (Table 5). A similar result was experienced by (Jiang et al., 2018), they concluded that in the long-term treatments of an experiment it is necessary to continuously use of manure with chemical fertilizers for better soil fertility, crop production, and soil organic carbon sustainability and sequestration. Nutrient content of soil both available and total increased with the application of inorganic plus manure as compared to a single application of fertilizer with time (Table 5), a similar result was found by (Wei et al. 2015 and Yin et al. 2018). The soil physicochemical and biological properties were significantly affected by soil organic carbon (Hayne et al., 1997). Soil organic carbon was increased over time in NPKM2 followed by NPKM, NPKS, NPK, and significantly decreased in CK. The result in our study indicates that the significant increase in organic carbon was due to manure application which enhances soil organic carbon and soil structure (Wagner et al., 2007). The grain yield under the maize-wheat cropping system over different fertilization times also increases in the combined application of organic and inorganic fertilization (Yang et al., 2016). The plant growth and biomass enhanced with manure amendment and regular soil inputs also enhance soil physical, chemical, and biological processes in the soil (Flie et al., 2007; Gul et al., 2015). The manure application increases the soil microbial community in soil and improved soil crop growth and soil health condition similar finding was observed by (Zhiyong et al. 2020 and Ozlu et al., 2019). The principal component analysis also showed that the fertilization input directly affected nutrients availability. The nitrogen, phosphorous, and potassium uptake increase the grain yield. The NU, PU, and KU showed a positive correlation in long term fertilization over 20 years (1990-2010) similar finding was observed by (Atli et al., 2011; Cambrolle et al. 2013, and Bessa et al. 2016) that relative yield was directly affected by organic and inorganic fertilization. These cluster methods (PCA and PLS-DA) generally showed differences among the samples of various groups by detecting the main variable which contributes and finding a correlation among the variables (Ramadan et al., 2006). Climate change plays a major role in crop production (Azam et al., 2020). The high relative yield was showed by NPKM2 and NPKM treatments as compared to the CK (Table 5). The increased fertilizer level is considered the main driving force of nitrogen and phosphorus losses from agricultural areas. In long-term fertilization dynamics, crop growth and soil health improved with combined application of inorganic and organic fertilization. The surface runoff and precipitation over the year of fertilization showed a positive relationship and when there was precipitation event runoff also occurred similar result was experienced by (Zhang et al., 
2011). The crop parameter KL refers to the crop extraction of water and its ability, it was 0.08 day $^{-1}$ from 0.8 and decreased with depth, similar to (Hammer et al., 2009). Soil water dynamics in the root zone required the best soil properties to simulate the use of soil water balance and requirement for the particular crop. Worldwide warming influences and changes the water cycle by altering the rainfall levels and variability in temperature, which affect the soil water moisture and flow reported by Ritchie (1998) and Holsten et al. (2009). An environmentally friendly and combined practice of modeling agriculture system can enhance agriculture production and it will not mitigate climatic changes. (Bai et al., 2013; Yi et al., 2018; Hong et al., 2019) suggested the threshold level of nitrogen and phosphorous fertilizer input to the soil system. Our result finding of NPKM was the best fit with his level while the level of NPKM2 exceeds which will result in the environmental hazards. Moreover (Pote et al., 1996) found that an extractable $\mathrm{P}$ concentration in a grassland soil of $50 \mathrm{mg} \mathrm{kg}^{-1}$ (equivalent to c. $20 \mathrm{mg}$ $\mathrm{P} \mathrm{kg}^{-1}$ ) gave a DRP concentration in overland flow of $0.5 \mathrm{mg} \mathrm{liter}{ }^{-1}$. For cultivated soils the quantity of $\mathrm{P}$ lost in overland flow can be much greater due to an additional particulate component (Sharpley et al., 2001). The nitrogen level in NPKM2 also showed increasing level, similar finding was showed by (Yuan et al., 2018). These results also showed that the level of nitrogen and phosphorous need to be minimized and the best management strategies need to be adopted to get high yield and reduce the risk of environmental pollution. The outcomes of the study indicate that chemical fertilizer and manure application is the best management strategy for regulating crop yield and improving soil health and crop yields.

\section{Conclusions}

The aim was to study the climatic impact over the 20-years and combined application of manure and chemical fertilizers. Significant differences in soil fertility and crop yields among different fertilization treatments were found. Sheep manure was applied with a rate of $30,000 \mathrm{~kg} \mathrm{ha}^{-1}$ and inorganic fertilizers over 20 years (1990-2010) significantly increased the crop yield, sustainability yield index, soil nutrients content, soil organic carbon, and organic carbon sequestration as compared to inorganic fertilization. Soil available nitrogen, total nitrogen, and organic matter (OC) play a vital role in crop grain production. The major driving force for crop yield in the combined use of long-term manure and inorganic fertilization was the available soil $\mathrm{N}, \mathrm{OC}$ and overall N. Soil $\mathrm{pH}$, which was directly influenced by $\mathrm{N}$ input, showed a direct impact on AP and an indirect impact on relative crop yield. Carbon production affected relative crop yield indirectly by directly influencing soil OC. The $\mathrm{pH}$ of the soil did not change significantly over the year of fertilization and non-significant effect on relative yield. Organic carbon and phosphorous significantly increased under the application of the treatment of inorganic and organic manure (sheep). Apparent phosphorous sand nitrogen balance exceeded the environmental risk threshold level under the NPKM2 treatment. The phosphorus and nitrogen balance exceeds the environmental risk threshold level in the treatments NPKM2 and NPKM, respectively. Our study concluded the level of phosphorus and nitrogen fertilizer needs to be decreased in organic and inorganic fertilizer. Therefore, the rate of phosphorous and nitrogen application needs to be minimized to reduced surplus nitrogen and phosphorous in the soil. The potassium showed a positive balance in inorganic and organic fertilization during 1990-2010 while negative balance was observed during 2000-2010. The 
precipitation and runoff were calculated through APSIM software and runoff exceeded the precipitation, which increases the nutrient losses and leads to environmental risk. The study showed the highest yield of grain in (maize-spring wheat-winter wheat) under inorganic and organic NPKM2 and NPKM as compared to inorganic treatments. The soil microbial activities enhanced with manure addition and also increased carbon level in the soil which leads to increased yield. Climate change due to the rising emissions of greenhouse gases, particularly carbon dioxide $\left(\mathrm{CO}_{2}\right)$, it is essential to evaluate its prospective influence on crop production and development. Applying the APSIM model to simulate the wheat-maize cropping system and climate model to study the impact of climatic change on the study sites. The climatic model in APSIM results showed that with a decrease of annual precipitation $(-10)$ and by increasing the temperature maximum and minimum $(+2,-2)$ and $\mathrm{CO}_{2}$ level $(600 \mathrm{ppm})$ these changes in the future climate will significantly affect the soil and environmental situations.

Acknowledgments. Acknowledgment is granted to the APSIM project, which assumes responsibility for quality control and a formal innovation system for the modeling software developed by APSIM free of charge for research and development use (see www.apsim.info for details). The authors are thankful to Dandan Han for technical support in our lab. This study is a part of the Ph.D. dissertation, which is supported by the Chinese government scholarship program. Acknowledgment is also granted to Abdul Walikhan University (AWKUM) Mardan Pakistan.

Funding. The soil data was provided by China National Soil Fertility and Fertilizer Effects Long-term Monitoring Network in Urumqi province- China for their unremitting efforts in the long-term experiment. The Ph.D. work is supported by the Chinese government scholarship program under 2017-2021.

Author contributions. Conceptualization, J.L and Y.M.; Methodology, N.T., and A.U., Writing Original Draft Preparation, N.T.; Data collection and analysis, H.L; Funding Acquisition, J.L.; Supervision, J.L and Y.M. All authors have read and agreed to the published version of the manuscript.

\section{REFERENCES}

[1] Atli, H. S., Aydin, Y., Arpaci, S., Acar, I., Karadag, S., Bilgel, L., Sarpkaya, K., Kaska, N., Kafkas, S., Ak, B. E. (2011): Determination of growth, bearing, yield and some quality characteristics of pistachio cultivars grafted on different rootstocks under irrigated conditions. - Acta Horticulturae 912: 289-294.

[2] Azam, M., Zhang, S., Abdelghany, A. M., Shaibu, A. S., Feng, Y., Li, Y., Tian, Y., Hong, H., Li, B., Sun, J. (2020): Seed isoflavone profiling of 1168 soybean accessions from major growing ecoregions in China. - Food Research International 10: 1-9.

[3] Bai, Z., Li, H., Yang, X., Zhou, B., Shi, X., Wang, B., Li, D., Shen, J., Chen, Q., Qin, W., Oenema, O., Zhang, F. (2013): The critical soil P levels for crop yield, soil fertility and environmental safety in different soil types. - Plant and Soil 372: 27-37.

[4] Bakht, J., Shafi, M., Jan, M. T., Shah, Z. (2009): Influence of crop residue management, cropping system and $\mathrm{N}$ fertilizer on soil $\mathrm{N}$ and $\mathrm{C}$ dynamics and sustainable wheat (Triticum aestivum L.) production. - Soil and Tillage Research 104: 233-240.

[5] Beaudoin, N., Launay, M., Sauboua, E., Ponsardin, G., Mary, B. (2008): Evaluation of the soil crop model STICS over 8 years against the "on farm" database of Bruyères catchment. - European Journal of Agronomy 29: 46-57.

[6] Bessa, L. A., Moreira, M. A., Silva, F. G., Mota, C. S., Vitorino, L. C. (2016): Growth, nutrient concentration and principal component analysis of Cagaita (Eugenia dysenterica DC.) seedlings grown in nutrient solution. - Australian Journal of Crop Science 10: 425433. 
[7] Brisson, N. (2003): An overview of the crop model STICS. - Europ. J. Agronomy 18: 309-332.

[8] Cambrolle, J., Mancilla-Leyton, J. M., Munoz-Valles, S., Figueroa-Luque, E., Luque, T., Figueroa, M. E. (2013): Effects of copper sulfate on growth and physiological responses of Limoniastrum monopetalum. - Environmental Science and Pollution Research 20: 8839-8847.

[9] Chavas, D. R., Izaurralde, R. C., Thomson, A. M., Gao, X. (2009): Long-term climate change impacts on agricultural productivity in eastern China. - Agricultural and Forest Meteorology 149: 1118-1128.

[10] Chen, M., Chen, J., Sun, F. (2008): Agricultural phosphorus flow and its environmental impacts in China. - Science of the Total Environment 405: 140-152.

[11] Das, A., Sharma, R. P., Chattopadhyaya, N., Rakshit, R. (2014): Yield trends and nutrient budgeting under a long-term (28 years) nutrient management in rice-wheat cropping system under subtropical climatic condition. - Plant, Soil and Environment 60: 351-357.

[12] Derpsch, R. (2003): Conservation Tillage, No-Tillage and Related Technologies. - In: García-Torres L., Benites J., Martínez-Vilela A., Holgado-Cabrera A. (eds.) Conservation Agriculture. Springer, Dordrecht, pp. 181-190.

[13] Doltra, J., Gallejones, P., Olesen, J. E., Hansen, S., Froseth, R. B., Krauss, M., Stalenga, J., Jonczyk, K., Martínez-Fernandez, A., Pacini, G. C. (2019): Simulating soil fertility management effects on crop yield and soil nitrogen dynamics in field trials under organic farming in Europe. - Field Crops Research 233: 1-11.

[14] Egan, G., McKenzie, P., Crawley, M., Fornara, D. A. (2019): Effects of grassland management on plant nitrogen use efficiency (NUE). Evidence from a long-term experiment. - Basic and Applied Ecology 41: 33-43.

[15] FAO (2009): The state of food and agriculture. - Choice Reviews Online 46: 1-10.

[16] Fliebach, A., Oberholzer, H. R., Gunst, L., Mader, P. (2007): Soil organic matter and biological soil quality indicators after 21 years of organic and conventional farming. Agriculture, Ecosystems and Environment 118: 273-284.

[17] Gai, X., Liu, H., Liu, J., Zhai, L., Yang, B., Wu, S., Ren, T., Lei, Q., Wang, H. (2018): Long-term benefits of combining chemical fertilizer and manure applications on crop yields and soil carbon and nitrogen stocks in North China Plain. - Agricultural Water Management 208: 384-392.

[18] Gaind, S., Nain, L. (2007): Chemical and biological properties of wheat soil in response to paddy straw incorporation and its biodegradation by fungal inoculants. Biodegradation 18: 495-503.

[19] Gul, S., Whalen, J. K., Thomas, B. W., Sachdeva, V., Deng, H. (2015): Physico-chemical properties and microbial responses in biochar-amended soils: mechanisms and future directions. - Agriculture, Ecosystems and Environment 206: 46-59.

[20] Hammer, G. L., Dong, Z., McLean, G., Doherty, A., Messina, C., Schussler, J., Zinselmeier, C., Paszkiewicz, S., Cooper, M. (2009): Can changes in canopy and/or root system architecture explain historical maize yield trends in the US. - Crop Science 49: 299-312.

[21] Han, K. H., Choi, W. J., Han, G. H., Yun, S. I., Yoo, S. H., Ro, H. M. (2004): Ureanitrogen transformation and compost-nitrogen mineralization in three different soils as affected by the interaction between both nitrogen inputs. - Biology and Fertility of Soils 39: 193-199.

[22] Haynes, R. J., Beare, M. H. (1997): Influence of six crop species on aggregate stability and some labile organic matter fractions. - Soil Biology and Biochemistry 29: 16471653.

[23] He, Y., Shi, Y., Liang, H., Hu, K., Hou, L. (2020): Soil water and nitrogen fluxes in response to climate change in a wheat-maize double cropping system. - Agronomy 10: 113. 
[24] Holsten, A., Vetter, T., Vohland, K., Krysanova, V. (2009): Impact of climate change on soil moisture dynamics in Brandenburg with a focus on nature conservation areas. Ecological Modelling 220: 2076-2087.

[25] Hong, X., Ma, C., Gao, J., Su, S., Li, T., Luo, Z., Duan, R., Wang, Y., Bai, L., Zeng, X. (2019): Effects of different green manure treatments on soil apparent $\mathrm{N}$ and $\mathrm{P}$ balance under a 34-year double-rice cropping system. - Journal of Soils and Sediments 19: 73-80.

[26] Hu, C., Xia, X., Chen, Y., Qiao, Y., Liu, D., Fan, J., Li, S. (2019): Yield, nitrogen use efficiency and balance response to thirty-five years of fertilization in paddy rice-upland wheat cropping system. - Plant, Soil and Environment 65: 55-62.

[27] Jackson, M. (1969): Soil Chemical Analysis: Advanced Course. - Parallel Press, Medison.

[28] Jiang, G., Zhang, W., Xu, M., Kuzyakov, Y., Zhang, X., Wang, J., Di, J., Murphy, D. V. (2018): Manure and mineral fertilizer effects on crop yield and soil carbon sequestration: a meta-analysis and modeling across China. - Global Biogeochemical Cycles 32: 16591672.

[29] Jin, X. C., Chu, Z. S., Yi, W. L., Hu, X. Z. (2005): Influence of phosphorus on Microcystis growth and the changes of other environmental factors. - Journal of Environmental Sciences 17: 937-941.

[30] Jones, J. W., Hoogenboom, G., Porter, C. H., Boote, K. J., Batchelor, W. D., Hunt, L. A., Wilkens, P. W., Singh, U., Gijsman, A. J., Ritchie, J. T. (2003): The DSSAT cropping system model. - European Journal of Agronomy 18: 235-265.

[31] Keating, B. A., Carberry, P. S., Hammer, G. L., Probert, M. E., Robertson, M. J., Holzworth, D., Huth, N. I., Hargreaves, J. N. G., Meinke, H., Hochman, Z., McLean, G., Verburg, K., Snow, V., Dimes, J. P., Silburn, M., Wang, E., Brown, S., Bristow, K. L., Asseng, S., Chapman, S., McCown, R. L., Freebairn, D. M., Smith, C. J. (2003b): An overview of APSIM, a model designed for farming systems simulation. - European Journal of Agronomy 18: 267-288.

[32] Kollas, C., Kersebaum, K. C., Nendel, C., Manevski, K., Müller, C., Palosuo, T., ArmasHerrera, C. M., Beaudoin, N., Bindi, M., Charfeddine, M., Conradt, T., Constantin, J., Eitzinger, J., Ewert, F., Ferrise, R., Gaiser, T., Cortazar-Atauri, I. G. de, Giglio, L., Hlavinka, P., Hoffmann, H., Hoffmann, M. P., Launay, M., Manderscheid, R., Mary, B., Mirschel, W., Moriondo, M., Olesen, J. E., Ozturk, I., Pacholski, A., Ripoche-Wachter, D., Roggero, P. P., Roncossek, S., Rotter, R. P., Ruget, F., Sharif, B., Trnka, M., Ventrella, D., Waha, K., Wegehenkel, M., Weigel, H. J., Wu, L. (2015): Crop rotation modelling-A European model intercomparison. - European Journal of Agronomy 70: 98111.

[33] LaHue, G. T., van Kessel, C., Linquist, B. A., Adviento-Borbe, M. A., Fonte, S. J. (2016): Residual effects of fertilization history increase nitrous oxide emissions from zero-N controls: implications for estimating fertilizer-induced emission factors. - Journal of Environmental Quality. 45: 1501-1508.

[34] Lal, R. (2008): Crop residues as soil amendments and feedstock for bioethanol production. - Waste Management 28: 747-758.

[35] Liu, E., Yan, C., Mei, X., He, W., Bing, S. H., Ding, L., Liu, Q., Liu, S., Fan, T. (2010): Long-term effect of chemical fertilizer, straw, and manure on soil chemical and biological properties in northwest China. - Geoderma 158: 173-180.

[36] Lobell, D. B., Asner, G. P. (2003): Climate and management contributions to recent trends in U. S. agricultural yields. - Science 299: 1032-1040.

[37] Lu, R. K. (2000): Analytical Methods of Soil Agricultural Chemistry. - China Agricultural Science and Technology Press, Beijing (in Chinese).

[38] McCown, R. L., Hammer, G. L., Hargreaves, J. N. G., Holzworth, D. P., Freebairn, D. M. (1996): APSIM: a novel software system for model development, model testing and simulation in agricultural systems research. - Agricultural Systems 50: 255-271. 
[39] Murphy, J., Riley, J. P. (1962): A modified single solution method for the determination of phosphate in natural waters. - Analytica Chimica Acta 27: 31-36.

[40] Nelson, D., Sommers, L. (1996): Total Carbon, Organic Carbon, and Organic Matter. In: Sparks, D. L. et al. (eds.) Methods of Soil Analysis: Part 3 Chemical Methods. Soil Science Society of America Book Series. Soil Science Society of America, Madison, WI, pp. 961-1010.

[41] OECD (2013): Health at a Glance 2013: OECD Indicators, OECD Compendium of Agrienvironmental Indicators. - OECD, Paris.

[42] Olsen, S. R., Cole, C. V., Watandbe, F., Dean, L. (1954): Estimation of Available Phosphorus in Soil by Extraction with Sodium Bicarbonate. - US Dept. of Agriculture, Washington, DC.

[43] Ouyang, W., Li, Z., Liu, J., Guo, J., Fang, F., Xiao, Y., Lu, L. (2017): Inventory of apparent nitrogen and phosphorus balance and risk of potential pollution in typical sloping cropland of purple soil in China. A case study in the Three Gorges Reservoir region. - Ecological Engineering 106: 620-628.

[44] Ozlu, E., Sandhu, S. S., Kumar, S., Arriaga, F. J. (2019): Soil health indicators impacted by long-term cattle manure and inorganic fertilizer application in a corn-soybean rotation of South Dakota. - Scientific Reports 9: 1-11.

[45] Page, A. L., Millar, R. H., Keeney, D. R. (1982): Methods of Soil Analysis, Part 2. - Am. Soc. Agron. Inc. and Soil Sci. Soc. Am. Inc. Publishers, Madison WI.

[46] Pansu, M. (2006): Handbook of Soil Analysis. Mineralogical, Organic and Inorganic Methods. - Springer, Berlin.

[47] Pote, D. H., Daniel, T. C., Sharpley, A. N., Moore Jr, P. A., Edwards, D. R., Nichols, D. J. (1996): Relating extractable soil phosphorus to phosphorus losses in runoff. - Journal of Environmental Quality 60: 855-859.

[48] Qiu, H., Ge, T., Liu, J., Chen, X., Hu, Y., Wu, J., Su, Y., Kuzyakov, Y. (2018): Effects of biotic and abiotic factors on soil organic matter mineralization: experiments and structural modeling analysis. - European Journal of Soil Biology 84: 27-34.

[49] Ramadan, Z., Jacobs, D., Grigorov, M., Kochhar, S. (2006): Metabolic profiling using principal component analysis, discriminant partial least squares, and genetic algorithms. Talanta 68(5): 1683-1691.

[50] Rasmussen, P. E., Goulding, K. W. T., Brown, J. R., Grace, P. R., Janzen, H. H., Korschens, M. (1998): Long-term agroecosystem experiments: assessing agricultural sustainability and global change. - Science 282: 893-896.

[51] Richardson, A. E., Hocking, P. J., Simpson, R. J., George, T. S. (2009): Plant mechanisms to optimise access to soil phosphorus. - Crop and Pasture Science 60(2): 124-143.

[52] Ritchie, J. (1998): Soil Water Balance and Plant Water Stress. - In: Tsuji G. Y., Hoogenboom G., Thornton P. K. (eds.) Understanding Options for Agricultural Production. Systems Approaches for Sustainable Agricultural Development, Vol. 7. Springer, Dordrecht, pp. 41-54.

[53] Saha, S., Saha, B., Ray, M., Mukhopadhyay, S. K., Halder, P., Das, A., Chatterjee, S., Pramanick, M. (2018): Integrated nutrient management (INM) on yield trends and sustainability, nutrient balance and soil fertility in a long-term (30 years) rice-wheat system in the Indo-Gangetic plains of India. - Journal of Plant Nutrition 41: 2365-2375.

[54] Sarkar, D., Baishya, L. K., Meitei, C. B., Naorem, G. C., Thokchom, R. C., Singh, J., Bhuvaneswari, S., Batabyal, K., Das, R., Padhan, D., Prakash, N., Rahman, F. H. (2018): Can sustainability of maize-mustard cropping system be achieved through balanced nutrient management? - F. Crop. Res. 225: 9-21.

[55] Shahid, M., Shukla, A. K., Bhattacharyya, P., Tripathi, R., Mohanty, S., Kumar, A., Lal, B., Gautam, P., Raja, R., Panda, B. B., Das, B., Nayak, A. K. (2016): Micronutrients (Fe, $\mathrm{Mn}, \mathrm{Zn}$ and $\mathrm{Cu}$ ) balance under long-term application of fertilizer and manure in a tropical rice-rice system. - Journal of Soils and Sediments 16: 737-747. 
[56] Sharpley, A. N., McDowell, R. W., Kleinman, P. J. A. (2001): Phosphorus loss from land to water: integrating agricultural and environmental management. - Plant and Soil 237: 287-307.

[57] Shi, Z., Li, D., Jing, Q., Cai, J., Jiang, D., Cao, W., Dai, T. (2012): Effects of nitrogen applications on soil nitrogen balance and nitrogen utilization of winter wheat in a ricewheat rotation. - Field Crops Research 127: 241-247.

[58] Singh, P. R., Rao, S. K., Bhaskarrao, U. M., Ready, M. N. (1990): Sustainability Index Under Different Management. - Annual Report. CRIDA, Hyderabad, India.

[59] Singh, R. J., Ghosh, B. N., Sharma, N. K., Patra, S., Dadhwal, K. S., Meena, V. S., Deshwal, J. S., Mishra, P. K. (2017): Effect of seven years of nutrient supplementation through organic and inorganic sources on productivity, soil and water conservation, and soil fertility changes of maize-wheat rotation in north-western Indian Himalayas. Agriculture, Ecosystems and Environment 249: 177-186.

[60] Stull, J., Dillon, C., Shearer, S., Isaacs, S. (2004): Using precision agriculture technology for economically optimal using precision agriculture technology for economically optimal strategic decisions: the case of CRP filter strip enrollment. - Journal of Sustainable Agriculture 24: 39-56.

[61] Tong, C., Hall, C. A. S., Wang, H. (2003): Land use change in rice, wheat and maize production in China (1961-1998). - Agriculture, Ecosystems and Environment 95: 523536.

[62] Ullah, A., Ma, Y., Li, J., Tahir, N., Hussain, B. (2020): Effective amendments on cadmium, arsenic, chromium and lead contaminated paddy soil for rice safety. Agronomy 10: 1-18.

[63] Wagner, S., Cattle, S. R., Scholten, T. (2007): Soil-aggregate formation as influenced by clay content and organic-matter amendment. - Journal of Plant Nutrition and Soil Science 170: $173-180$.

[64] Watson, C. A., Atkinson, D., Gosling, P., Jackson, L. R., Rayns, F. W. (2002): Managing soil fertility in organic farming systems. - Soil Use and Management 18: 239-247.

[65] Wei, T., Zhang, P., Wang, K., Ding, R., Yang, B., Nie, J., Jia, Z., Han, Q. (2015): Effects of wheat straw incorporation on the availability of soil nutrients and enzyme activities in semiarid areas. - PLoS ONE 10: 1-15.

[66] Wei, H., Peiyu, L., Ning, A., Fangang, C., Shiyu, Z., Kun, C., Jinfeng, Y., Xiaori, H. (2020): Manure application increased crop yields by promoting nitrogen use efficiency in the soils of 40-year soybean-maize rotation. - Sci Rep 10: 14882.

[67] Xin, X., Qin, S., Zhang, J., Zhu, A., Yang, W., Zhang, X. (2017): Yield, phosphorus use efficiency and balance response to substituting long-term chemical fertilizer use with organic manure in a wheat-maize system. - Field Crops Research 208: 27-33.

[68] Yang, H., Feng, J., Zhai, S., Dai, Y., Xu, M., Wu, J., Shen, M., Bian, X., Koide, R. T., Liu, J. (2016): Soil \& Tillage Research Long-term ditch-buried straw return alters soil water potential, temperature, and microbial communities in a rice-wheat rotation system. - Soil \& Tillage Research 163: 21-31.

[69] Yang, X., Ni, K., Shi, Y. Yi, X., Zhang, Q., Fang, L., Ma, L. Feng, Ruan, J. (2018): Effects of long-term nitrogen application on soil acidification and solution chemistry of a tea plantation in China. - Agriculture, Ecosystems and Environment 252: 72-84.

[70] Yang, Y. J., Lei, T., Du, W., Liang, C. L., Li, H. D., Lv, J. L. (2020): Substituting chemical fertilizer nitrogen with organic manure and comparing their nitrogen use efficiency and winter wheat yield. - The Journal of Agricultural Science 1-7.

[71] Yi, Y., Li, F., Zhang, M., Yuan, Y., Zhu, M., Guo, W., Zhu, X., Li, C. (2018): Is there a nitrogen fertilizer threshold emitting less $\mathrm{N}_{2} \mathrm{O}$ with the prerequisite of high wheat production? - PLoS ONE 13: 1-14.

[72] Yin, H., Zhao, W., Li, T., Cheng, X., Liu, Q. (2018): Balancing straw returning and chemical fertilizers in China: role of straw nutrient resources. - Renewable and Sustainable Energy Reviews 81: 2695-2702. 
[73] Zhang, F., Cui, Z., Fan, M., Zhang, W., Chen, X., Jiang, R. (2011): Integrated soil-crop system management: reducing environmental risk while increasing crop productivity and improving nutrient use efficiency in China. - Journal of Environmental Quality 40: 10511057.

[74] Zhang, H., Xu, M., Shi, X., Li, Z., Huang, Q., Wang, X. (2010): Rice yield, potassium uptake and apparent balance under long-term fertilization in rice-based cropping systems in southern China. - Nutrient Cycling in Agroecosystems 88(3): 341-349.

[75] Zhang, W. J., Wang, X. J., Xu, M. G., Huang, S. M., Liu, H., Peng, C. (2010): Soil organic carbon dynamics under long-term fertilizations in arable land of northern China. - Biogeosciences 7: 409-425.

[76] Zhang, W., Xu, M., Wang, X., Huang, Q., Nie, J., Li, Z., Li, S., Hwang, S. W., Lee, K. B. (2012): Effects of organic amendments on soil carbon sequestration in paddy fields of subtropical China. - Journal of Soils and Sediments 12: 457-470.

[77] Zhang, X., Wang, S., Sun, H., Chen, S., Shao, L., Liu, X. (2013): Contribution of cultivar, fertilizer and weather to yield variation of winter wheat over three decades: a case study in the North China Plain. - European Journal of Agronomy 50: 52-59.

[78] Zhang, X., Zhu, A., Xin, X., Yang, W., Zhang, J., Ding, S. (2018): Tillage and residue management for long-term wheat-maize cropping in the North China Plain: I. Crop yield and integrated soil fertility index. - Field Crops Research 221: 157-165.

[79] Zhang, Y. L., Sun, C. X., Chen, Z. H., Zhang, G. N., Chen, L. J., Wu, Z. J. (2019): Stoichiometric analyses of soil nutrients and enzymes in a Cambisol soil treated with inorganic fertilizers or manures for 26 years. - Geoderma 353: 382-390.

[80] Zhao, X., Liu, B. Y., Liu, S. L., Qi, J. Y., Wang, X., Pu, C., Li, S. S., Zhang, X. Z., Yang, X. G., Lal, R., Chen, F., Zhang, H. L. (2020): Sustaining crop production in China's cropland by crop residue retention: a meta-analysis. - Land Degradation and Development 3: 694-709.

[81] Zhiyong, Z., Xiuxiu, D., Shaoming, W., Xiaozhen, P. (2020): Benefits of organic manure combined with biochar amendments to cotton root growth and yield under continuous cropping systems in Xinjiang, China. - Sci Rep 10: 4718.

[82] Zhu, Q., Liu, X., Hao, T., Zeng, M., Shen, J., Zhang, F., De Vries, W. (2018): Modeling soil acidification in typical Chinese cropping systems. - Science of the Total Environment 613-614: 1339-1348.

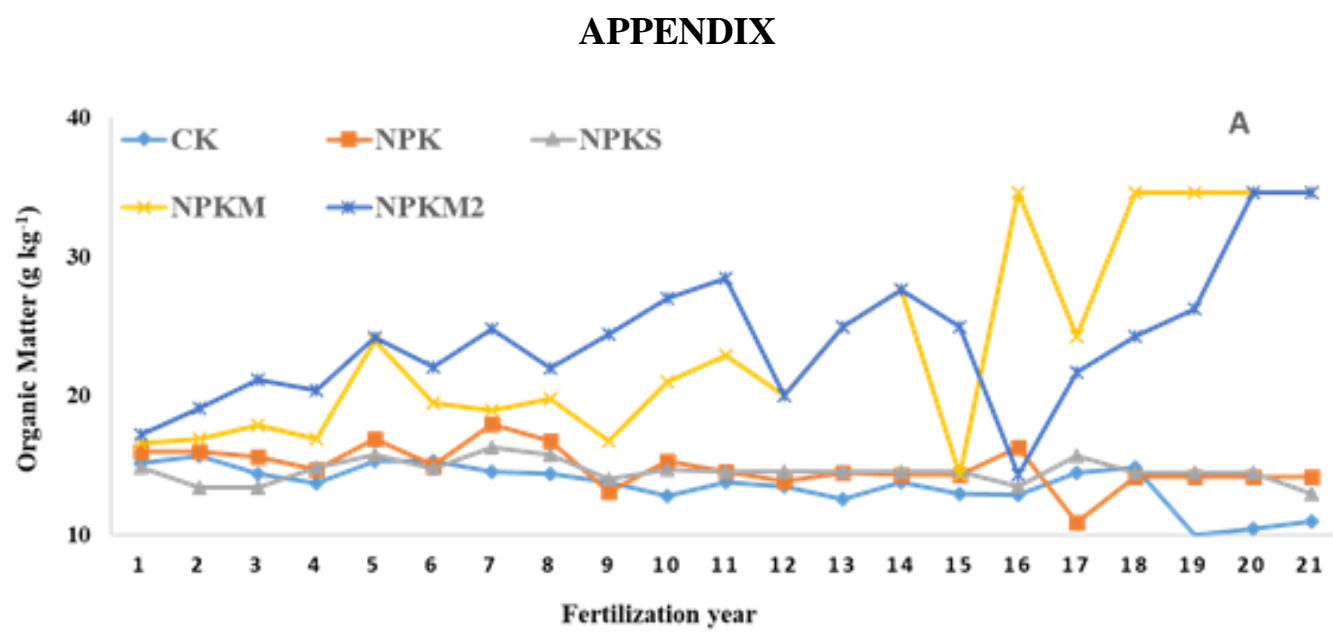

Figure A1. Fertilization years' vs organic matter g. $\mathrm{kg}^{-1}$ changes over 20 years 
Table A1. Crop type with crop variety, sowing dates and seedling time and harvesting date of all the crop at Urumqi, Xinxiang China

\begin{tabular}{|c|c|c|c|c|c|c|}
\hline Year & Crop type & Crop variety & Sowing period & Seedling stage & $\begin{array}{l}\text { Heading period/trolling } \\
\text { period }\end{array}$ & Harvest period \\
\hline 1990 & Maize & SC-704 & $1990-4-21,22$ & $1990-5-1$ & & $1990-9-23,24$ \\
\hline 1991 & Spring wheat & Xinchun 2 & 1991-4-4 & 1991-4-12 & $1991-6-5$ & $1991-7-15$ \\
\hline 1992 & Winter wheat & Xindong 15 & $1991-9-23$ & $1991-10-3$ & & $1992-7-14$ \\
\hline 1993 & Maize & SC-704 & $1993-4-22,24$ & $1993-5-2$ & $1993-7-8$ & $1993-9-28,29$ \\
\hline 1994 & Spring wheat & Xinchun 2 & 1994-4-3 & 1994-4-12 & & $1994-7-18$ \\
\hline 1995 & Winter wheat & 5148 & $1994-9-21$ & 1994-10-2 & & $1995-7-15$ \\
\hline 1996 & Maize & SC-704 & $1996-4-26$ & $1996-5-4$ & & 1996-10-1, 2 \\
\hline 1997 & Spring wheat & Xindong 19 & 1996-10-1 & 1996-10-12 & & $1997-7-2$ \\
\hline 1998 & Winter wheat & Xindong 19 & $1997-9-22$ & 1997-10-1 & & $1998-7-21$ \\
\hline 2000 & Maize & Xinyu 7 & $2000-5-1$ & $2000-5-10$ & $2000-7-8$ & $2000-9-25,26$ \\
\hline 2001 & Maize & SC-704 & $2001-4-2122$ & $2001-5-1$ & & $2001-9-23,24$ \\
\hline 2002 & Spring wheat & Xinchun 2 & $2002-4-4$ & $2002-4-12$ & $2002-6-5$ & $2002-7-15$ \\
\hline 2003 & Winter wheat & & $2003-9-23$ & $2003-10-3$ & & $2003-7-14$ \\
\hline 2004 & Maize & Xindong 15 & $2004-4-22,24$ & $2004-5-2$ & $2004-7-8$ & 2004-9-28,29 \\
\hline 2005 & Spring wheat & SC-704 & $2005-4-3$ & $2005-4-12$ & & $2005-7-18$ \\
\hline 2006 & Winter wheat & & 2006-9-21 & 20064-10-2 & & $2006-7-15$ \\
\hline 2007 & Maize & Xinchun 2 & $2007-4-26$ & $2007-5-4$ & & 2006-10-1, 2 \\
\hline 2008 & Spring wheat & & $2008-10-1$ & 2008-10-12 & & $2007-7-2$ \\
\hline 2009 & Winter wheat & 5148 & $2009-9-22$ & 2009-10-1 & & $2009-7-21$ \\
\hline 2010 & Maize & SC-704 & $2010-5-1$ & $2010-5-10$ & $2000-7-8$ & $2010-9-25,26$ \\
\hline
\end{tabular}


Table A2. Bulk density and SAT, DUL all calculation table depth wise

\begin{tabular}{|c|c|c|c|c|c|c|c|c|c|c|}
\hline \multicolumn{11}{|c|}{ BULK DENSITY \& DRAINED UPPER LIMIT } \\
\hline Sample No & $\begin{array}{c}\text { Depth } \\
\text { range } \\
(\mathrm{cm})\end{array}$ & $\begin{array}{c}\text { DUL } \\
\text { Gravimetric } \\
(\mathbf{g} / \mathbf{g}) \\
\mathbf{G} \\
((\text { Wet-Dry }) / \text { Dry }) \\
=(\boldsymbol{E}-\boldsymbol{F}) / \boldsymbol{F}\end{array}$ & $\begin{array}{c}\text { DUL } \\
\text { Gravimetric } \\
(\%) \\
H \\
\text { Grav }(g / g) * 100 \\
=G \times 100\end{array}$ & $\begin{array}{c}\text { Bulk density } \\
\text { (g/cc) } \\
\text { I } \\
\text { DrwWt/Core Vol } \\
=\text { F/D }\end{array}$ & $\begin{array}{c}\text { DUL } \\
\text { Volumetric } \\
(\mathbf{m m} / \mathbf{m m}) \\
\mathbf{J} \\
\text { Grav }(\mathbf{g} / \mathbf{g}) * \mathbf{B D} \\
=\boldsymbol{G} \times I\end{array}$ & $\begin{array}{c}\text { DUL } \\
\text { Volumetric } \\
(\%) \\
\text { K } \\
\text { Grav\% } x \text { BD } \\
=\boldsymbol{H} \times \boldsymbol{x} I\end{array}$ & $\begin{array}{c}\text { PO } \\
\text { Volumetric } \\
(\mathrm{mm} / \mathrm{mm}) \\
\mathrm{L} \\
(1-B D / 2.65) \\
=(1-1 / 2.65)\end{array}$ & $\begin{array}{c}\text { SAT } \\
\text { Volumetric } \\
(\mathbf{m m} / \mathbf{m m}) \\
M \\
(P O-0.03) \\
=L-0.03\end{array}$ & $\begin{array}{c}\text { SAT } \\
\text { Volumetric } \\
(\%) \\
\mathrm{N} \\
\left.\begin{array}{c}S A T(\mathrm{~mm} / \mathrm{mm}) \\
=\end{array}\right) 100 \\
=M \times 100\end{array}$ & $\begin{array}{c}\text { SAT-DUL } \\
(\mathrm{mm} / \mathrm{mm}) \\
0 \\
\text { SAT-DUL } \\
=M-J\end{array}$ \\
\hline 1 & $0-15$ & 0.368 & 36.8 & 1.35 & 0.497 & 49.74 & 0.49 & 0.461 & 46.06 & -0.04 \\
\hline 2 & $15-30$ & 0.365 & 36.5 & 1.36 & 0.497 & 49.70 & 0.49 & 0.457 & 45.68 & -0.04 \\
\hline 3 & $30-60$ & 0.341 & 34.1 & 1.44 & 0.491 & 49.14 & 0.46 & 0.427 & 42.66 & -0.06 \\
\hline 4 & $60-90$ & 0.344 & 34.4 & 1.43 & 0.492 & 49.24 & 0.46 & 0.430 & 43.04 & -0.06 \\
\hline 5 & $90-100$ & 0.365 & 36.5 & 1.36 & 0.497 & 49.70 & 0.49 & 0.457 & 45.68 & -0.04 \\
\hline 6 & $100-12$ & 0.381 & 38.1 & 1.31 & 0.498 & 49.85 & 0.51 & 0.476 & 47.57 & -0.02 \\
\hline 7 & $120-140$ & 0.405 & 40.5 & 1.23 & 0.498 & 49.78 & 0.54 & 0.506 & 50.58 & 0.01 \\
\hline 8 & $140-160$ & 0.399 & 39.9 & 1.25 & 0.498 & 49.83 & 0.53 & 0.499 & 49.88 & 0.00 \\
\hline
\end{tabular}

Table A3. Crop and soil parameters used in APSIM

\begin{tabular}{|c|c|c|c|c|c|c|c|c|c|c|c|c|c|c|}
\hline Depth & $\begin{array}{c}\text { BD } \\
(\mathrm{g} / \mathrm{cc})\end{array}$ & $\underset{(\mathbf{m m} / \mathbf{m m})}{\text { Air Dry }}$ & $\underset{(\mathrm{mm} / \mathrm{mm})}{\mathbf{L L 1 5}}$ & $\begin{array}{c}\text { DUL } \\
(\mathbf{m m} / \mathbf{m m})\end{array}$ & $\underset{(\mathrm{mm} / \mathrm{mm})}{\mathrm{SAT}}$ & $\begin{array}{c}\mathbf{K S} \\
\text { (mm/day) }\end{array}$ & $\begin{array}{l}\text { Maize LL } \\
(\mathbf{m m} / \mathbf{m m})\end{array}$ & \begin{tabular}{|c} 
Maize PAWC \\
285.0
\end{tabular} & $\underset{\text { Maize KL }}{\text { (/day }}$ & $\begin{array}{c}\text { Maize XF } \\
(0-1)\end{array}$ & $\begin{array}{l}\text { Wheat LL } \\
(\mathrm{mm} / \mathrm{mm})\end{array}$ & $\begin{array}{c}\text { Wheat PAWC } \\
\text { 324.0 }\end{array}$ & $\begin{array}{c}\text { Wheat KL } \\
\text { (/day) }\end{array}$ & $\begin{array}{c}\text { Wheat XF } \\
(0-1)\end{array}$ \\
\hline $0-15$ & 1.25 & 0.18 & 0.2 & 0.497 & 0.461 & 0.11 & 0.11 & 36 & 0.08 & 1 & 0.11 & 36 & 0.06 & 1 \\
\hline $15-30$ & 1.25 & 0.18 & 0.2 & 0.497 & 0.457 & 0.14 & 0.14 & 37.5 & 0.08 & 1 & 0.13 & 39 & 0.06 & 1 \\
\hline $30-60$ & 1.25 & 0.18 & 0.2 & 0.491 & 0.427 & 0.16 & 0.16 & 34.5 & 0.08 & 1 & 0.13 & 39 & 0.04 & 1 \\
\hline $60-90$ & 1.26 & 0.18 & 0.19 & 0.492 & 0.430 & 0.17 & 0.17 & 33 & 0.08 & 1 & 0.15 & 36 & 0.04 & 0.9 \\
\hline $90-100$ & 1.27 & 0.18 & 0.17 & 0.497 & 0.457 & 0.19 & 0.19 & 30 & 0.06 & 1 & 0.15 & 36 & 0.04 & 0.9 \\
\hline $100-120$ & 1.27 & 0.18 & 0.16 & 0.498 & 0.476 & 0.2 & 0.2 & 57 & 0.04 & 1 & 0.16 & 69 & 0.04 & 0.7 \\
\hline $120-140$ & 1.27 & 0.18 & 0.14 & 0.498 & 0.506 & 0.2 & 0.2 & 57 & 0.03 & 1 & 0.16 & 69 & 0.02 & 0.7 \\
\hline $140-160$ & 1.27 & 0.18 & 0.14 & 0.498 & 0.499 & 0.2 & 0.2 & 57 & 0.03 & 1 & 0.16 & 69 & 0.02 & 0.7 \\
\hline
\end{tabular}

APPLIED ECOLOGY AND ENVIRONMENTAL RESEARCH 19(3):1827-1855.

http://www.aloki.hu • ISSN 15891623 (Print) • ISSN 17850037 (Online)

DOI: http://dx.doi.org/10.15666/aeer/1903_18271855

○ 2021, ALÖKI Kft., Budapest, Hungary 
Table A4. Climatic change model observed and predicted values over 20 years of simulation under the climatic change

\begin{tabular}{c|c|c}
\hline 1990-2010 & Observed & Predicted \\
\hline Rain 650 (mm) & 0.64 & 0.57 \\
Runoff $(\mathrm{mm})$ & 0.43 & 0.40 \\
N03 $\left(\mathrm{kg} \mathrm{ha}^{-1}\right)$ & 1444.00 & 1422.54 \\
Leaching_fr (0-1) & 0.75 & 0.73 \\
Drain (mm) & 0.00 & 0.00 \\
Total $\mathrm{NH}_{4}(\mathrm{~kg} / \mathrm{ha})$ & 35.12 & 41.73 \\
Organic matter & -0.45 & -0.45 \\
Nitrogen balance (kg/ha) & 14.38 & 19.23 \\
Essential soil water (esw (mm)) & 191.21 & 181.54 \\
\hline
\end{tabular}

Table A5. Climatic change model output variables

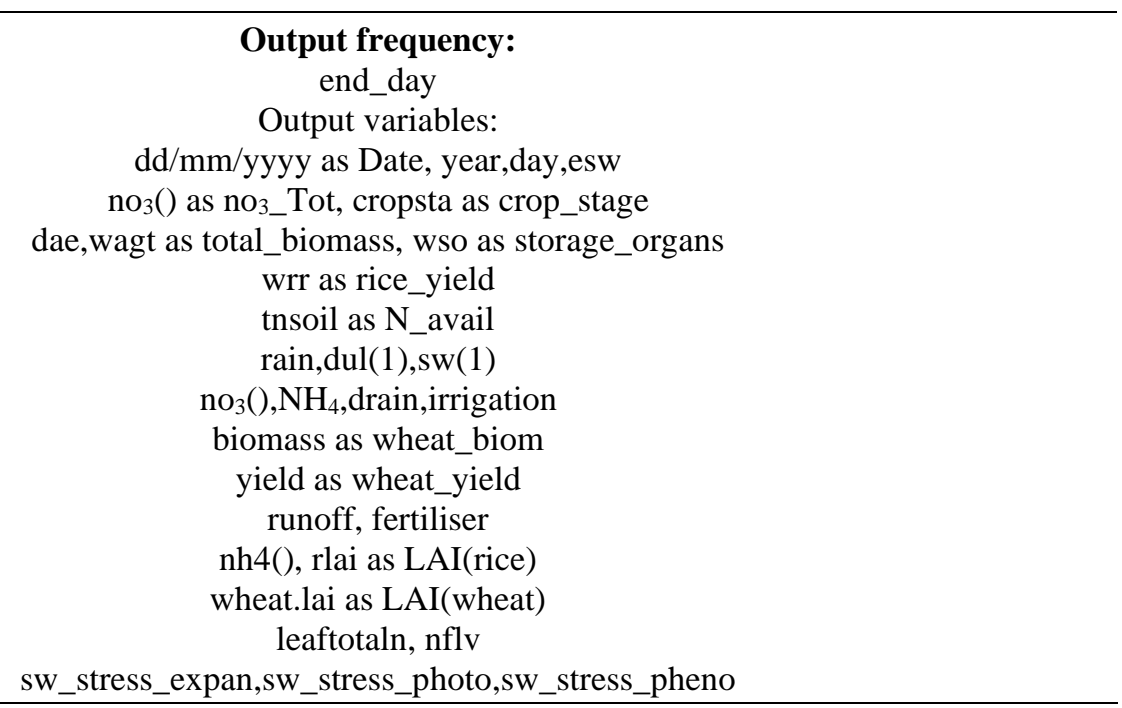

Table A6. Annual soil organic carbon stock and organic matter vs fertilization graph

\begin{tabular}{c|c|c}
\hline Treatments & Carbon rate & A*bd* depth/10 \\
\hline CK & 0.18 & 0.45 \\
NPK & 0.12 & 0.31 \\
NPKM & 0.90 & 2.2 \\
NPKS & 0.02 & 0.06 \\
NPKM2 & 0.44 & 1.08 \\
\hline
\end{tabular}


Table A7. Descriptive statistics of the data

\begin{tabular}{|c|c|c|c|c|c|c|}
\hline Crop & Treatments & Mean & Minimum & Maximum & Std. deviation & Std. error \\
\hline Maize & $\mathrm{NU}$ & 122.08 & 76.05 & 136.75 & 25.89 & 11.58 \\
\hline \multirow[t]{6}{*}{$1990-2000$} & PU & 17.13 & 7.11 & 24.26 & 6.92 & 3.10 \\
\hline & KU & 0.00 & 0.00 & 0.00 & 0.00 & 0.00 \\
\hline & NBal & 151.86 & -3.72 & 435.39 & 169.49 & 75.80 \\
\hline & PBal & 42.71 & -7.11 & 97.04 & 37.04 & 16.56 \\
\hline & KBal & 142.40 & 0.00 & 413.00 & 170.97 & 76.46 \\
\hline & GY & 5.95 & 4.41 & 6.66 & 0.93 & 0.42 \\
\hline \multirow{7}{*}{$\begin{array}{c}\text { Corn } \\
2000-2010\end{array}$} & $\mathrm{NU}$ & 157.11 & 61.10 & 200.96 & 54.99 & 54.99 \\
\hline & PU & 28.72 & 8.00 & 43.53 & 12.89 & 12.89 \\
\hline & KU & 275.14 & 134.57 & 337.26 & 81.87 & 81.87 \\
\hline & NBal & 107.49 & -61.10 & 369.04 & 160.43 & 160.43 \\
\hline & PBal & 31.12 & -8.00 & 77.77 & 30.95 & 30.95 \\
\hline & KBal & -132.58 & -275.49 & 75.97 & 135.54 & 135.54 \\
\hline & GY & 7.42 & 3.22 & 9.01 & 2.39 & 2.39 \\
\hline \multirow{7}{*}{$\begin{array}{c}\text { Spring wheat } \\
1990-2000\end{array}$} & $\mathrm{NU}$ & 81.13 & 21.59 & 106.33 & 15.35 & 34.33 \\
\hline & $\mathrm{PU}$ & 12.98 & 2.73 & 18.20 & 2.82 & 6.30 \\
\hline & KU & 23.74 & 4.65 & 35.81 & 5.16 & 11.54 \\
\hline & $\mathrm{NBal}$ & 155.59 & -12.24 & 347.95 & 57.56 & 128.70 \\
\hline & PBal & 38.28 & -0.94 & 77.70 & 12.44 & 27.82 \\
\hline & KBal & 118.60 & 5.00 & 303.00 & 53.94 & 120.60 \\
\hline & GY & 2.73 & 1.02 & 3.82 & 0.47 & 1.05 \\
\hline \multirow[t]{7}{*}{$2000-2010$} & $\mathrm{NU}$ & 134.77 & 35.36 & 195.84 & 26.73 & 59.77 \\
\hline & PU & 17.25 & 4.93 & 23.97 & 3.29 & 7.37 \\
\hline & KU & 116.85 & 29.71 & 165.25 & 24.19 & 54.08 \\
\hline & NBal & 129.83 & -35.36 & 374.16 & 67.67 & 151.31 \\
\hline & PBal & 42.59 & -4.93 & 97.33 & 16.34 & 36.54 \\
\hline & KBal & 25.71 & -78.11 & 247.99 & 59.86 & 133.86 \\
\hline & GY & 2.69 & 0.69 & 3.42 & 0.51 & 1.14 \\
\hline \multirow{7}{*}{$\begin{array}{l}\text { Winter wheat } \\
1990-2000\end{array}$} & $\mathrm{NU}$ & 157.11 & 61.10 & 200.96 & 24.59 & 54.99 \\
\hline & PU & 28.72 & 8.00 & 43.53 & 5.77 & 12.89 \\
\hline & KU & 275.14 & 134.57 & 337.26 & 36.61 & 81.87 \\
\hline & NBal & 107.49 & -61.10 & 369.04 & 71.75 & 160.43 \\
\hline & PBal & 31.12 & -8.00 & 77.77 & 13.84 & 30.95 \\
\hline & $\mathrm{KBal}$ & -132.58 & -275.49 & 75.97 & 60.62 & 135.54 \\
\hline & GY & 7.42 & 3.22 & 9.01 & 1.07 & 2.39 \\
\hline \multirow[t]{7}{*}{$2000-2010$} & $\mathrm{NU}$ & 105.31 & 18.58 & 153.90 & 24.16 & 54.03 \\
\hline & PU & 39.07 & 7.75 & 54.80 & 8.64 & 19.33 \\
\hline & $\mathrm{KU}$ & 59.17 & 7.61 & 87.00 & 14.26 & 31.89 \\
\hline & $\mathrm{NBal}$ & 159.29 & -18.58 & 416.10 & 70.89 & 158.51 \\
\hline & PBal & 20.77 & -7.75 & 66.50 & 12.36 & 27.63 \\
\hline & $\mathrm{KBal}$ & 83.39 & -26.25 & 336.24 & 68.56 & 153.30 \\
\hline & GY & 4.70 & 1.02 & 6.58 & 0.99 & 2.21 \\
\hline
\end{tabular}

